\title{
EL ÉXITO SOCIAL ENTRE LOS EMIGRANTES PENINSULARES EN EL PERÚ: INTEGRACIÓN, PRESTIGIO Y MEMORIA
}

\section{Social Success among Peninsular Immigrants in Peru: Integration, Prestige and Memory}

\author{
Jorge PÉREZ LEÓN ${ }^{1}$ \\ Universidad de Valladolid \\ perezleon.jorge@yahoo.es
}

Fecha de recepción: 14/05/2013

Fecha de aceptación definitiva: 12/11/2013

RESUMEN: Este trabajo analiza las estrategias sociales empleadas por algunos peninsulares en el Perú del siglo XVIII. Después de conseguir cierta prosperidad económica gracias a los negocios o el ejercicio de cargos en la administración, estas personas persiguieron la aceptación y el reconocimiento por parte de sus convecinos, un objetivo que pasaba necesariamente por su integración. El matrimonio con criollas, la obtención de toda clase de cargos honoríficos, el ennoblecimiento y los legados y fundaciones post mortem fueron algunas de las estrategias utilizadas. La elección como muestra de estudio de un grupo de pretendientes a la hidalguía nos proporciona un modelo de las prácticas sociales adoptadas por estos grupos en ascenso y su pugna por hacerse un sitio en la sociedad peruana.

Palabras clave: emigración; integración; prestigio; nobleza; ascenso social; Perú.

1. Este artículo forma parte de nuestra tesis doctoral inédita, realizada con el apoyo de una Beca FPI cofinanciada por la Junta de Castilla y León y el Fondo Social Europeo. Tesis doctoral PÉREZ LEÓn, Jorge. Hidalgos indianos Ante la Real Chancillería de Valladolid. El caso peruano. Defendida en la Universidad de Valladolid en 2012. http://uvadoc.uva.es/handle/10324/961 [consulta: 10-04-2013]. 
ABSTRACT: This paper analyzes the social strategies used by some Spaniards in Peru during the eighteenth century. After achieving a certain amount of prosperity through business or by holding positions in the administration, these individuals pursued acceptance and recognition from their neighbors, an aim that necessarily led to integration. Marrying Creole women, obtaining all kinds of honorary positions along with ennoblement and post mortem legacies and foundations were some of the strategies used. The choice of a group of candidates for a position of nobility as the study sample provides a model of the social practices adopted by these groups, which were growing and fighting for their place in Peruvian society.

Key words: emigration; integration; prestige; nobility; social mobility; Peru.

En la sociedad española del Antiguo Régimen, donde valores como el honor se exaltaban hasta límites insospechados, era común que los personajes enriquecidos, especialmente aquellos que procedían de otros lugares, pretendiesen elevar su estatus social. Con este objetivo desarrollarían toda serie de estrategias que les permitiesen alcanzar el respeto de sus convecinos. El análisis de estas estrategias de promoción social será el objetivo del presente trabajo, tomando como ejemplo las desplegadas por peninsulares en el Perú. Para ello asumimos como hipótesis inicial que el grado de vinculación e integración de un individuo en su comunidades de residencia resulta fundamental para entender el porqué de la puesta en marcha de tales estrategias, cuyo fin último, como hemos señalado, sería el de elevar su estatus social, un proceso que frecuentemente culminaba con el ennoblecimiento de iure $^{2}$. El peninsular que desease mejorar su estatus en alguna localidad americana, amén de poseer cierto patrimonio o un esclarecido origen, debía de pasar por una serie de etapas que atestiguasen su deseo de integración en la colectividad de acogida además de realzar su reputación mediante la acumulación de signos de distinción propios del sistema de honor estamental.

Durante los últimos años hemos dedicado nuestras investigaciones al estudio de los efectos jurídicos y sociales que tenían los despachos de hidalguía obtenidos ante las Reales Chancillerías peninsulares, concretamente los solicitados por peninsulares residentes en el Perú durante el periodo borbónico. La demostrada conexión de muchas de estas solicitudes de hidalguía con los procesos de ascenso social emprendidos por sus peticionarios nos proporciona una muestra de estudio lo suficientemente sólida para estudiar esta cuestión ${ }^{3}$. Muchos de estos pretendientes a la hidalguía eran individuos meritorios, pertenecientes a grupos

2. Unas estrategias perfectamente contrastadas entre los comerciantes de Cádiz, que incluían procesos de ennoblecimiento a partir de ejecutorias de hidalguía, hábitos de órdenes militares y títulos nobiliarios. ANES FERNÁNDEZ, Lidia. "Comercio con América y títulos de nobleza: Cádiz en el siglo XVIII". Cuadernos Dieciochistas, 2001, 2, pp. 109-149.

3. En el apéndice final mostramos algunas de estas exitosas trayectorias individuales. 
socioeconómicos pujantes (principalmente comerciantes y burócratas) que aspiraban a elevar su estatus mediante la acreditación de un "buen origen" lo que conseguían mediante estos despachos de hidalguía. Para este trabajo hemos estudiado a un total de 72 pretendientes de origen peninsular que residieron en Perú que incoaron causas de hidalguía ante la Real Chancillería de Valladolid entre 1700 y 1820. El estudio de esta muestra heterogénea, cuyos únicos denominadores comunes son la procedencia peninsular y el deseo de ascender socialmente ${ }^{4}$, proporciona a esta investigación una transversalidad suficiente para componer una visión de conjunto sobre las estrategias de integración y ascenso social. La casuística observada demuestra la generalización de una serie de prácticas sociales tanto entre las elites como en los sectores en ascenso.

En nuestro propósito de dotar de unidad a nuestro discurso hemos seleccionado únicamente aquellas estrategias que se hallaban más extendidas entre los individuos analizados: en primer lugar, los enlaces matrimoniales, entendidos aquí como un signo decisivo de su integración y un paso imprescindible para su aceptación social; en segundo lugar, la participación en todo orden de agrupaciones y órganos colegiados (cofradías, Inquisición, milicias, cabildo) que profundizan en ese ánimo de integración y les proveen de nuevos contactos y de posibilidades de promoción; el reconocimiento del estatus mediante certificaciones tales como los despachos de hidalguía - de los cuales no nos ocuparemos aquí- y distinciones nobiliarias como los hábitos de órdenes militares y los Títulos de Castilla; y, por último, el uso de la herencia material e inmaterial como instrumento de promoción social post mortem.

\section{LOS ENLACES MATRIMONIALES, UN PRIMER PASO HACIA LA INTEGRACIÓN}

En la sociedad indiana, e hispana en general, la institución matrimonial era un importante instrumento de promoción social y económica ${ }^{5}$. Gracias a estos enlaces, algunos de los pretendientes a la hidalguía lograron un considerable prestigio social a pesar de que muchos de ellos, por muy hidalgos de sangre que fuesen, tenían unos orígenes ciertamente modestos. En este apartado trataremos de desentrañar qué tipo de relaciones o vínculos dieron lugar a estas uniones.

4. Sobre los antecedentes y trayectoria profesional de los pretendientes Vid. Tesis doctoral PÉREZ LEón, Jorge. Hidalgos indianos... y "Emigración al Nuevo Mundo y la "fuerza del origen": su huella en los procesos de hidalguía”. Naveg@mérica. Revista electrónica de la Asociación Española de Americanistas [en línea], 2013, n. ${ }^{\circ}$ 10. Disponible en http://revistas.um.es/navegamerica [Consulta: 1-04-2013].

5. Stabili, M. ${ }^{a}$ Rosaria. "Hidalgos americanos. La formación de la élite vasco-castellana de Santiago de Chile en el siglo XVIII". En SCHRÖTER, Bernd y BüschgES, Christian (eds.). Beneméritos, aristócratas y empresarios. Identidades y estructuras sociales de las capas altas urbanas en la América bispánica. 1. ${ }^{a}$ ed. Madrid: Vervuert, 1999, p. 144. 
Generalmente, los criterios que regían enlaces matrimoniales de los peninsulares en América giraban en torno a afinidades e intereses como el parentesco, el paisanaje o las relaciones profesionales. De hecho, esta clase de vínculos tuvieron una notable influencia en la mayor parte de las relaciones sociales durante el Antiguo Régimen. El beneplácito paterno tenía una influencia decisiva en estos enlaces, que funcionaban como un recurso para establecer alianzas entre grupos familiares. Según esta lógica, cuantos más enlaces entre dos familias se produjesen, más estrechos serían sus vínculos, lo que fomentaría una endogamia matrimonial en la que la mujer criolla constituía un pilar fundamental en la mayor parte de las relaciones sociales y de parentesco ${ }^{6}$.

En muchas ocasiones debemos retroceder hasta la Península para hallar el germen de estas uniones. Allí era común que las gentes de concejos cercanos estuviesen emparentadas desde varias generaciones atrás ${ }^{7}$. En algunos casos estos vínculos familiares o geográficos tendrían su continuidad en América, cristalizando incluso en uniones con las hijas de coterráneos y contribuyendo a reforzar esos lazos preexistentes ${ }^{8}$. Así, José Martín Bustamante y Quevedo, natural de la villa cántabra de Cartes, contrajo matrimonio con M. ${ }^{a}$ Antonia de Bustamante y Uría, hija de Juan Antonio de Bustamante Quijano, prior del consulado de Lima y también originario de Cartes, y de Rosa de Uría9. Estas uniones simbólicas entre coterráneos permitían a los recién llegados una integración ventajosa en familias que ya poseían cierto renombre. El comillano Manuel Hilario de la Torre Quirós casaría con Águeda de Tagle y Bracho, hija de su socio y paisano José Bernardo de Tagle Bracho, marqués de Torre Tagle ${ }^{10}$. Un ejemplo paradigmático de esta solidaridad -o endogamia- familiar y regional sería el de los hermanos santanderinos Isidro y Joaquín Abarca. Tras prosperar como comerciante bajo la protección de su tío Gerónimo de Angulo, el primero contraería matrimonio con su prima carnal, Rosa Gutiérrez de Cosío, condesa de San Isidro y viuda de Gerónimo de Angulo, mientras que Joaquín lo haría con su prima segunda M. ${ }^{a}$ del Carmen Angulo y Gutiérrez de Cosío, fruto del primer matrimonio de la

6. Sobre la importancia de la mujer criolla como articuladora de los nexos de relación mediante el matrimonio Vid. LIRA MONTT, Luis. "Reflexiones en torno del llamado "matriarcado" colonial hispanoamericano". Hidalguía, 1988, 206, pp. 15-28.

7. ANES FERNÁNDEZ, Lidia. "Nobleza asturiana en el siglo XVIII". En FAYA DíAZ, M. ${ }^{a}$ Ángeles

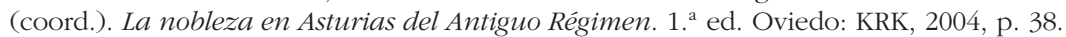

8. Socolow, Susan. Los mercaderes del Buenos Aires virreinal: familia y comercio. $1 .^{a}$ ed. Buenos Aires: Ediciones La Flor, 1991, pp. 31-32.

9. Registro del matrimonio de José Martín de Bustamante (y Quevedo) con M. ${ }^{a}$ Antonia de Bustamante (y Uría). Lima, 15 de enero de 1762. Archivo Arzobispal de Lima [en adelante AAL], Parroquia de la Iglesia del Sagrario, Libro de matrimonios n. ${ }^{\circ} 10$, f. $35 \mathrm{v}$.

10. Registro del matrimonio de Manuel de la Torre con Águeda Josefa de Tagle Bracho. Lima, 14 de agosto de 1737. AAL, Parroquia de la Iglesia del Sagrario, Libro de matrimonios n. ${ }^{\circ}$ 9, f. $14 \mathrm{v}$. 
condesa $^{11}$. A pesar de ser estas uniones teóricamente desiguales, en las que unos comerciantes enriquecidos accedían a las capas superiores de honorabilidad a través de matrimonios con miembros de la nobleza titulada, debemos tener en cuenta que los títulos nobiliarios de Tagle Bracho y de San Isidro habían sido concedidos a comerciantes enriquecidos por lo que estos enlaces representan la continuidad de los sistemas de relación propios de una aristocracia mercantil $^{12}$. Una situación semejante se advierte en el caso del orensano Cayetano Fernández Maldonado, cónsul del tribunal del consulado limeño, quien contrajo nupcias con M. ${ }^{a}$ Manuela de Sarriá y Cárdenas, hija y nieta de comerciantes de origen guipuzcoano y hermana del conde de Casa Sarriá, un notable comerciante asentado en Cádiz ${ }^{13}$.

Y es que a la hora de elegir a un candidato para las hijas estas afinidades profesionales podían tener igual o más importancia que los lazos regionales ${ }^{14}$. Esta clase de vínculos tuvo un considerable peso en los matrimonios que concertaron las familias de los De Lavalle y De la Cuadra procedentes de las Encartaciones vizcaínas. Ambas familias, originarias de San Julián de Musques, estaban emparentadas, ya que Simón Lavalle y la Bodega era primo segundo del padre del limeño Pedro José de la Cuadra y Mollinedo y, por tanto, tío tercero de este. El padre de Pedro José, el comerciante vizcaíno Juan Manuel Pelayo de la Cuadra y Foncerrada, de cuyo matrimonio con Dorotea Mollinedo ya hemos hecho mención, casó a sus hijas Rosa y Josefa con los hermanos Diego y Antonio Sáenz de Tejada respectivamente, originarios de La Rioja y también dedicados al comercio ${ }^{15}$ (vid. Figura 1).

11. Registro del matrimonio de Isidro Abarca con Rosa Cosío, condesa de San Isidro. Lima, 14 de diciembre de 1774. AAL, Parroquia de la Iglesia del Sagrario, Libro de matrimonios n. ${ }^{\circ} 10$, ff. $142 \mathrm{v}-143 \mathrm{r}$. Registro del matrimonio de Joaquín Abarca con la señora M. ${ }^{a}$ del Carmen de Angulo y Cosío. Lima, 19 de marzo de 1779. AAL, Parroquia de la Iglesia del Sagrario, Libro de matrimonios n. ${ }^{\circ} 10$, ff. 235 r-v.

12. MAZZEO DE VIVÓ, Cristina. "Mecanismos de supervivencia en la élite mercantil limeña a fines del siglo XVIII y principios del XIX". En SCHRÖTER, Bernd y BüsCHGES, Christian (eds.). Beneméritos, aristócratas y empresarios. Identidades y estructuras sociales de las capas altas urbanas en la América bispánica. 1. ${ }^{\mathrm{a}}$ ed. Madrid, 1999, pp. 72-73.

13. Poder para testar otorgado conjuntamente por Cayetano Fernández Maldonado y su esposa María Manuela de Sarriá y Cárdenas. Lima, 8 de noviembre de 1788. Archivo General de la Nación del Perú [en adelante AGN], Notarial, Gervasio de Figueroa, prot. 461, ff. 618r-620v.

14. Una endogamia profesional que ha sido ya contrastada también en otros ámbitos como las audiencias, donde abundaban las relaciones de afinidad y parentesco político entre togados amén de las prohibidas uniones con nativas de la jurisdicción, lo que revela la influencia e intereses de estos enlaces que podían deparar estos enlaces. LoHmann VillenA, Guillermo. Los ministros de la Audiencia de Lima en el reinado de los Borbones: 1700-1821. 1. ${ }^{a}$ ed. Sevilla: Escuela de Estudios Hispano-Americanos, 1974, pp. LIII-LXVII.

15. Registro del Matrimonio de Diego Sáenz de Tejada con M. ${ }^{a}$ Rosa de la Cuadra y Mollinedo. Lima, 1 de septiembre de 1764. AAL, Parroquia de la Iglesia del Sagrario, Libro de matrimonios n. ${ }^{\circ}$, f. 357v. Registro del Matrimonio de Antonio Sáenz de Tejada con M. ${ }^{\text {a }}$ Rosa de la Cuadra y Mollinedo. Lima, 7 de junio de 1777. AAL, Parroquia de la Iglesia del Sagrario, Libro de matrimonios n. ${ }^{\circ}$ 10, f. 183r. 
Juan José Martínz de Phillos (Cm) $\infty \mathbf{M}^{2}$ Josefa de Cacho Lavalle

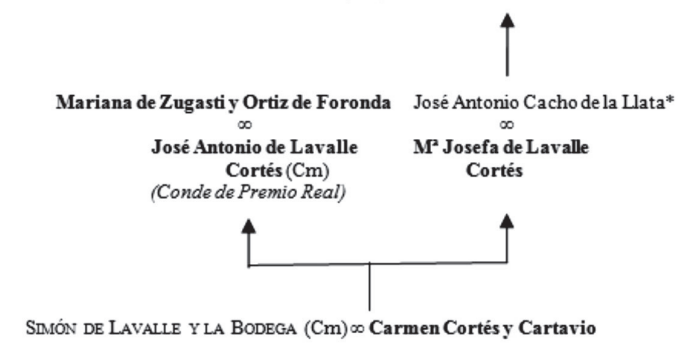

SMNóN DE LAVALLE Y LA BODEGA (Cm) $\infty$ Carmen Cortés y Cartavio

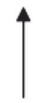

Pedro de Lavalle $\infty$ Isabel de la Bodega y Cuadra

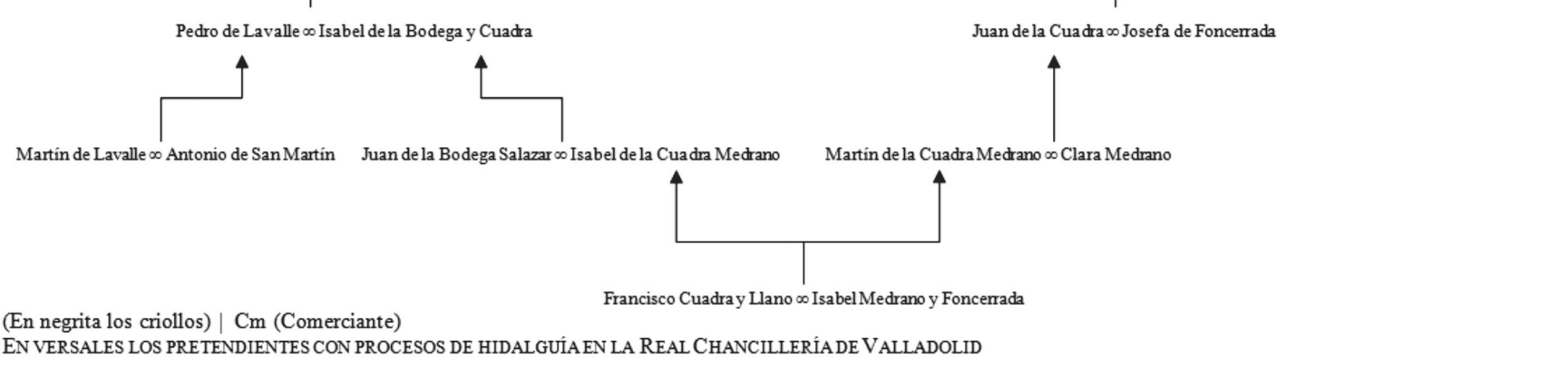

EN VERSALES LOS PRETENDIENTES CON PROCESOS DE HIDALGUIA EN LA REAL CHANCILLERÍA DE VALLADOLID

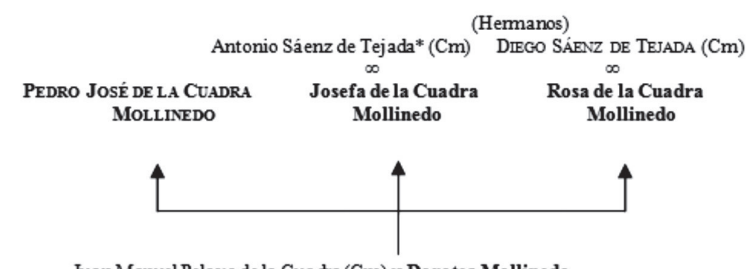

Juan Manuel Pelayo de la Cuadra (Cm) $\infty$ Dorotea Mollinedo

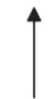

Juan de la Cuadra $\infty$ Josefa de Foncerrada

Fuente: Elaboración propia a partir de los procesos de vizcainía de Simón de Lavalle y Pedro José de la Cuadra. ARChV, Registro-Vizcainías, C. 19-5 y 15-3; MAzzeO, Cristina. El comercio libre en el Perú... Anexos II y III. * Antonio Sáenz de Tejada y José Antonio Cacho y Llata también solicitaron el reconocimiento de su hidalguía en la Real Chancillería de Valladolid en 1772 y 1771 respectivamente. ARCHV, Sala Hijosdalgo-pleitos, C.1145-59 y 1343-29. 
En cuanto a los miembros de la administración real hemos constatado que sus enlaces, más que a la afinidad profesional entre suegro y yerno, se debieron a la influencia de factores como el prestigio y la influencia derivada de estos cargos. Solo así se explican matrimonios como el de Juan Agustín Frade y Sierra, oficial de las Cajas de Lima, con Rosa Ilarduy Martínez de Saavedra, hija del receptor del Santo Oficio; o el de José Lucas de Gorbea y Vadillo, oidor de la audiencia de Chile y posteriormente fiscal de Lima, casado con la chilena Teresa Calvo de Encalada y Recabarren, hija de Manuel Calvo de Encalada y Chacón, marqués de Villapalma de la Encalada ${ }^{16}$.

Recordemos que, jurídicamente, estos enlaces implicaban una relación contractual en la que cada parte aportaba un capital o inversión a la unión conyugal: la dote y las arras. Las cantidades traídas al matrimonio bajo ambos conceptos son una buena referencia para conocer no solo el poder adquisitivo sino también el estatus de los contrayentes.

En la Tabla 1 recogemos algunas de las cuantías aportadas y recibidas por los pretendientes en las capitulaciones matrimoniales, donde se asentaban los recursos económicos de los cónyuges. La dote -cantidad aportada por la familia de la esposa- serviría fundamentalmente para asegurar el bienestar de la mujer, ya que tras la disolución del matrimonio o la muerte de alguno de los cónyuges estas cantidades debían ser reintegradas a esta o a su familia.

Estas aportaciones económicas pueden interpretarse como una manifestación más del despliegue suntuario de que hacía gala la élite limeña por lo que no es casualidad que las dotes más cuantiosas fuesen entregadas a los que se unieron con mujeres pertenecientes a grandes familias de la nobleza titulada como es el caso del matrimonio de Joaquín con M. ${ }^{a}$ Carmen Angulo, única hija de la condesa de San Isidro; o el de Manuel Hilario de la Torre Quirós con Águeda de Tagle y Bracho, hija del marqués de Torre Tagle. Fuera de estos matrimonios con mujeres pertenecientes a la aristocracia limeña el monto de las dotes restantes apenas excede los 30.000 pesos. Por ello resulta sorprendente la cuantía de la dote entregada al oficial de la Real Hacienda Juan Agustín Frade y Sierra por su suegro, el

\footnotetext{
Sobre las redes familiares y vínculos creados por los comerciantes de Lima. Para más información sobre estos enlaces entre familias de comerciantes Vid. MAZZEO DE VIVÓ, Cristina. "Estrategias de control social y económico en la élite mercantil de Lima en su tránsito de la colonia a la república". En GuerRA, Margarita y Roullón, Denisse (eds.). Historias paralelas. Actas del Primer Congreso de Historia Perú-México. 1. a ed. Lima: Colegio de Michoacán-Pontificia Universidad Católica del Perú, 2005, pp. 281-310 y Rizo PATRÓN, Paul. "Vinculación parental y social de los comerciantes de Lima a fines del periodo colonial". En MAZZEO, Cristina Ana. Los comerciantes limeños a fines del siglo XVIII. Capacidad y cohesión de una élite, 1750-1825. 1. ${ }^{\mathrm{a}}$ ed. Lima: Pontificia Universidad Católica del Perú, 1999, pp. 17-27.

16. Lohmann Villena, Guillermo. Los ministros de la Audiencia de Lima..., p. 51.
} 
receptor del Santo Oficio Manuel Ilarduy, que ascendía a nada menos que 62.000 $\operatorname{pesos}^{17}$.

Tabla 1

DOTES Y ARRAS (EN PESOS)

\begin{tabular}{|l|r|r|}
\hline \multicolumn{1}{|c|}{ CONTRAYENTES } & \multicolumn{1}{|c|}{ DOTE } & \multicolumn{1}{c|}{ ARRAS } \\
\hline Joaquín Abarca y M. ${ }^{a}$ Carmen de Angulo & 232.668 & 4.000 \\
\hline Manuel Hilario de la Torre y Quirós y Águeda de Tagle Bracho & 65.000 & \\
\hline Juan Agustín Frade y Sierra y Rosa de Ilarduy & 62.000 & \\
\hline $\begin{array}{l}\text { Francisco de Ocharán y Mollinedo y Mariana Carrillo de Córdoba } \\
\text { y Sancho-Dávila }\end{array}$ & 39.026 & 35.803 \\
\hline $\begin{array}{l}\text { José Antonio de Santiuste y Rosa M. }{ }^{\text {a }} \text { Fernández Valdivieso y } \\
\text { Urquizu }\end{array}$ & 30.000 & 3.000 \\
\hline Diego Sáenz de Tejada y Rosa de la Cuadra y Mollinedo & 20.317 & \\
\hline $\begin{array}{l}\text { Antonio Miguel de Arriaga Gurbista y M. }{ }^{a} \text { Josefa Huidobro y } \\
\text { Echeverría }\end{array}$ & 10.245 & \\
\hline Simón de Lavalle y M. ${ }^{a}$ Carmen Cortés & 10.000 & 2.000 \\
\hline $\begin{array}{l}\text { Martín Antonio de Aramburu y Echeverría y Manuela Rodríguez } \\
\text { y Preceda }\end{array}$ & 9.240 & \\
\hline $\begin{array}{l}\text { Domingo de la Guerra Sánchez de Cosío y Agustina Gallegos } \\
\text { de Loza }\end{array}$ & 6.965 & 1.000 \\
\hline Francisco Álvarez Calderón y María Escolástica Ramírez & 4.020 & 3.000 \\
\hline Alonso Carrió y Lavandera y Petronila Matute y Melgarejo & \\
\hline
\end{tabular}

Fuente: Elaboración propia a partir de AGN, Notarial (diversos testamentos y recibos dotales) y de los trabajos de "Los comerciantes vascos en el virreinato peruano". En Escobedo Mansilla, Ronald [et al.]. Los vascos y América, Actas de las Jornadas sobre el comercio vasco con América en el siglo XVIII y la Real Compañia Guipuzcoana de Caracas en el II Centenario de Carlos III. Bilbao, 1989, p. 83; MAzzeo, Cristina Ana. El Comercio Libre en el Perú. Las estrategias de un comerciante criollo: José Antonio de Lavalle y Cortés, 1777-1785. Lima: PUCP, 1994, p. 75 y TuRISO SEBASTIÁN, Jesús. Comerciantes españoles en la Lima Borbónica (1701-1761). 1. ${ }^{a}$ ed. Valladolid: Universidad de Valladolid, 2002, p. 146.

Pero no siempre la cuantía de las dotes reflejaba verdaderamente la influencia de los cónyuges. Es el caso del enlace del asturiano Alonso Carrió y Lavandera. En 1750 contrajo matrimonio con Petronila Matute y Melgarejo ${ }^{18}$, que pertenecía a una familia que controlaba la Casa de la Moneda de Lima, pues era nieta por línea materna del ensayador mayor Félix Cristóbal Cano Melgarejo, hija de Pablo Ma-

17. A diferencia de las restantes dotes incluidas en la muestra, compuestas íntegramente por dinero en efectivo, en este caso Juan Agustín Frade y Sierra percibió varías partidas en diferentes conceptos: 30.000 pesos en moneda tallada y hasta 10.000 pesos en diamantes claros, plata labrada y menaje de casa, así como 12.000 pesos como mejora de dote. Poder para testar otorgado por Juan Agustín Frade y Sierra. Lima, 18 de julio de 1746. AGN, Notarial, Francisco Roldán, prot. 929, f. 413r.

18. Recibo dotal de Alonso Carrió y Lavandera a Petronila Matute y Melgarejo. Lima, 23 de mayo de 1750. AGN, Colección Moreyra, D1. 16-441. 
tute de Vargas, fiel de moneda, y hermana de Pablo Matute Melgarejo, ensayador mayor de plata y oro y afinador de metal ${ }^{19}$. Probablemente la razón de que la dote entregada fuese tan escasa se debió a que, por entonces, Alonso era un simple advenedizo peninsular que hasta años después no se convertiría en administrador de la Renta de Correos.

En cuanto a las arras -la contribución por parte del esposo, cuya cuantía no debía de exceder de 10\% de su caudal-, resulta significativo que en ningún caso las cantidades se aproximen a los 6.000-10.000 pesos que Rizo-Patrón considera habituales entre las personas de la élite limeña ${ }^{20}$. En estos casos estaríamos ante esposos que, procedentes de sectores en ascenso, enlazan con mujeres de la elite. Generalmente comerciantes, como el montañés Joaquín Abarca, casado nada menos que con su prima, María del Carmen de Angulo, hija del conde de San Isidro. En otras ocasiones esta desigualdad social entre los consortes se manifiesta en la premura con que el esposo busca ennoblecerse. Así, el también comerciante Isidro Abarca, hermano de Joaquín, poco después de contraer matrimonio con la condesa de San Isidro, solicitaría un testimonio de su hidalguía ante la Real Chancillería de Valladolid y un hábito de la orden de Santiago, lo que demuestra su voluntad de mostrarse como un candidato aceptable para contraer matrimonio con toda una condesa ${ }^{21}$. Sin duda alguna, este gesto tenía como fin primordial justificar la idoneidad de Abarca ante la comunidad y no tanto ante su futura esposa, con la que estaba emparentado y que además era viuda de Gerónimo de Angulo, tío y antiguo protector del futuro esposo.

Pero no todos los pretendientes consideraron que el matrimonio fuese una prioridad. Son varios los ejemplos de personas que, a pesar de acumular un patrimonio considerable, conservaron su soltería. Es el caso del asturiano Toribio Menéndez Valdés, que dejaría un hijo natural, y ordenaría, además de múltiples y cuantiosas limosnas y mandas piadosas, que se fundase un mayorazgo en Gijón ${ }^{22}$; el laredano José Fernández de la Lastra nombraría a su padre heredero de todos sus bienes entre los que se contaban numerosas joyas, menaje y otros objetos de oro, plata y piedras preciosas ${ }^{23}$. Tampoco parece factible que fuese la falta de

19. Información Ad perpetuam rei Memoriam de Pablo Matute Melgarejo. Lima, junio de 1767. AGN, Colección Moreyra, D1. 9-233.

20. Rizo-Patrón Boylan, Paul. Linaje, dote y poder: la nobleza de Lima de 1700 a 1850. . $^{\mathrm{a}}$ ed. Lima: Pontificia Universidad Católica del Perú, 2001, p. 131.

21. Registro del matrimonio de Isidro Abarca con Rosa Cosío, condesa de San Isidro. Lima, 14 de diciembre de 1774. AAL, Parroquia de la Iglesia del Sagrario, Libro de matrimonios n. ${ }^{\circ} 10$, ff. $142 \mathrm{v}-143 \mathrm{r}$. Despacho de hidalguía de Isidro y Joaquín de Abarca (1776). Archivo de la Real Chancillería de Valladolid [en adelante ARChV], Sala Hijosdalgo-pleitos, C. 977-23. Pruebas para la concesión de hábito de Isidro Abarca (1776). Archivo Histórico Nacional [en adelante AHN], Órdenes, Santiago, exp. 10.

22. Testamento de Toribio Menéndez de Valdés. Lima, 11 de junio de 1774. AGN, Notarial, Valentín de Torres Preciado, prot. 1071, ff. 156-186v.

23. Testamento de José Fernández de la Lastra. Lima, 20 de marzo de 1776. AGN, Notarial, Valentín de Torres Preciado, prot. 1067, ff. 107r-108r. 
contactos lo que les impidiese casar con mujeres de buena familia. Francisco de Lombera, por ejemplo, era familiar y paisano de grandes comerciantes montañeses como Isidro Abarca, conde de San Isidro, o de Francisco Álvarez Calderón. Al igual que Menéndez Valdés, Lombera tenía tres hijas naturales a las que legaría 21.000 pesos para su manutención, si bien la mayor parte de sus bienes -estimados en 200.000 pesos una vez deducidas las deudas- fue a parar a su madre ${ }^{24}$. ¿Por qué estas uniones no llegaron a concretarse formalmente? Aunque no resulta una cuestión sencilla consideramos verosímil la hipótesis planteada por Socolow, quien sostiene que muchas veces estas mujeres no eran socialmente aceptables ya que carecían de relaciones con el mundo comercial ${ }^{25}$.

\section{RECONOCIMIENTO Y PRESTIGIO EN LA COMUNIDAD LOCAL}

El matrimonio con una mujer criolla podía atestiguar la voluntad de integración de los peninsulares, pero este gesto no siempre bastaba para conseguir el respeto de sus convecinos. La participación en agrupaciones colectivas o el desempeño de cargos que denotasen una cierta notoriedad permitiría a estos peninsulares profundizar en su asimilación. En una sociedad abierta a una continua inmigración como era la peruana, la admisión en corporaciones tenía una considerable importancia ya que favorecía la integración e interactuación de estos emigrantes no solo con otros peninsulares sino también con los criollos.

En este sentido debemos destacar el papel de hermandades y cofradías. Aunque todas estas corporaciones tenían una misma vocación religiosa y asistencial, mantenían distintos criterios a la hora de reclutar a sus cofrades. Tomemos como referencia dos cofradías con sede en Lima: la Cofradía de Aránzazu y en la Archicofradía de la Santísima Veracruz. La primera guardaba una diferencia sustancial con su gemela mexicana -en la que únicamente se admitían como hermanos a vasco-navarros ${ }^{26}$ - ya que, aunque integrada mayoritariamente por vasco-navarros (naturales del señorío de Vizcaya, provincia de Guipúzcoa, y los descendientes de ellos, así como por naturales del reino de Navarra y provincia de Álava), también estaba abierta a gentes procedentes de las cuatro villas de la costa de la Montaña (Laredo, Castrourdiales, Santander y San Vicente de la Barquera) ${ }^{27}$. Esta apertura de la cofradía peruana probablemente estaba en relación con un ambiente mer-

24. Testamento de Francisco Lombera. Lima, 25 de febrero de 1775. AGN, Notarial, Valentín de Torres Preciado, prot. 1066, ff. 674r-679r.

25. Socolow, Susan. Los mercaderes del Buenos Aires..., pp. 58-59.

26. Luque Alcalde, Elisa. La cofradía de Aránzazu de México (1691-1799). 1. a ed. Pamplona: Eunate, 1995, pp. 48-49.

27. Punto primero del estatuto fundacional. Citado por LOHMANN VILLENA, Guillermo. "La Ilustre Hermandad de Nuestra Señora de Aránzazu de Lima”. En ARANA PéREZ, Ignacio (coord.). Los vascos y América. Ideas, hechos, hombres. 1. ${ }^{a}$ ed. Madrid: Espasa-Calpe, 1990, p. 206. De ahí que montañeses, como el laredano José Antonio Santander y Alvarado, solicitasen ser "sepultado en la Iglesia de su 
cantil más distendido que el mexicano. En Nueva España esta discriminación probablemente era una consecuencia de la pugna entre montañeses y vascongados por el control del consulado. Por el contrario, la admisión de gente procedente de localidades de la Montaña en la cofradía peruana puede interpretarse como una señal de hermanamiento entre ambos colectivos dado que tanto vascongados como montañeses compartían un similar aprecio por la hidalguía y la limpieza de sangre. La vinculación a la cofradía de Aránzazu gozaría de cierta estima social ya que, por encima de su componente de identidad territorial -pues su fin primordial era el de asistir a personas convalecientes o desvalidas originarias de dichas provincias- se entendía que sus integrantes eran personas de origen esclarecido tal y como establecían sus constituciones ${ }^{28}$. Avanzado el siglo XVIII la cofradía de Aránzazu hubo de compartir su papel como centro de sociabilidad y vínculo con la tierra de origen de los vasco-navarros con la Real Sociedad Bascongada de Amigos del País, círculo cultural ideado para impulsar el desarrollo del país, y que reuniría a lo más selecto del colectivo vascongado en España y en América a finales de la centuria. En la sede limeña encontramos acreditados entre sus miembros a vizcaínos notables como el comerciante Francisco de Ocharán y Mollinedo o el ministro de la audiencia de Lima José Lucas de Gorbea y Vadillo; en Arequipa, al administrador de la renta de correos de dicha ciudad, el alavés Juan José de Arechavala ${ }^{29}$.

La Archicofradía de la Santísima Veracruz, adscrita al convento de Santo Domingo, se convirtió rápidamente en una corporación de especial prestigio. En ella solo eran admitidas las personas de probada calidad y notoria hidalguía por lo que ser hermano veinticuatro llegó a considerarse prueba de nobleza, pasando a formar parte de ella los círculos más exclusivos de la sociedad virreinal ${ }^{30}$. Estas

convento grande en la bóveda de nuestra señora de Aránzazum. Poder para testar de José Antonio Santander. Lima, 30 de abril de 1766. AGN, Notarial, Juan Bautista Tenorio y Palacios, prot. 1015, f. 419r.

28. Así se precisa en la segunda constitución del estatuto fundacional de la cofradía limeña: “... todos los que hubieren de recibidos en ella sean originarios de las partes y lugares de suso referidas o sus descendientes por vía de varón nobles y limpios de conocido nacimiento y opinión para lo cual se advertirá con particular cuidado que no se admita ni entre en la dicha hermandad ni menos se entierre en su capilla persona alguna que esté manchada o infamada...". Citado por LOHMANN VILLENA, Guillermo. "La Ilustre Hermandad de...", p. 207.

29. Lohmann Villena, Guillermo. "Los comerciantes vascos en el virreinato peruano". En EscoBEDo Mansilla, Ronald [et al.]. Los vascos y América, Actas de las Jornadas sobre el comercio vasco con América en el siglo XVIII y la Real Compañia Guipuzcoana de Caracas en el II Centenario de Carlos III. 1. ${ }^{a}$ ed. Bilbao: Laida, 1989, p. 95; Unzueta ECHEvarría, Antonio. "Los vascos de Arequipa y la cofradía y capilla de Nuestra Señora de Aránzazu». En Álvarez Gila, Oscar y ARrieta ElizAlde, Elisa (eds.). Las buellas de Aránzazu en América. I Congreso Internacional "Aránzazu y los franciscanos vascos en América", celebrado del 11 al 15 de diciembre de 2001. 1. ${ }^{a}$ ed. Donostia: Eusko Ikaskuntza, 2001, p. 128.

30. SÁnChez-CONCHA BARrios, Rafael. "La devoción a la Cruz en el Perú y la Archicofradía de la Vera Cruz de Lima (siglos XVI-XVIII)". En IV Congreso Internacional de Hermandades y Cofradias de la Santa Veracruz celebrado en Zamora los dias 25, 26 y 27 de septiembre de 2008. Zamora: 2008, p. 764. 
veinticuatrías fueron ocupadas preferentemente por miembros de la aristocracia limeña, altos cargos de la administración virreinal (virreyes, oidores) y grandes comerciantes, lo que resulta interesante a efectos de conocer la relevancia social e integración de los pretendientes ${ }^{31}$.

Por lo general, el acceso a cargos honoríficos dentro del ámbito local sugiere que el individuo, además de contar con importantes recursos económicos, deseaba obtener reconocimiento social y disfrutar de los privilegios e inmunidades asociados a sus fueros corporativos. Concretamente nos centraremos en tres de estos oficios: las familiaturas del Santo Oficio, los oficiales de milicias y cargos de cabildo (regidor, alcalde ordinario, etc.). Estos nombramientos, junto a muchos otros, contribuyeron a marcar las distancias entre la nobleza y la plebe en América, forjando un amplio corpus de actos distintivos ${ }^{32}$ sobre el que se apoyarían las élites locales.

El ingreso en el Santo Oficio de la Inquisición tenía una especial significación social, ya que era la institución encargada de velar por la pureza de las costumbres y los valores morales y religiosos. Por lo tanto la pertenencia al Santo Oficio garantizaba la posesión de una serie de cualidades muy estimadas en la sociedad española de la época. En este sentido las familiaturas -rango inferior del Santo Oficio- jugaron un importante papel en las estrategias de promoción social al ser los cargos más accesibles y que no requerían de una formación específica. La condición de familiar del Santo Oficio suponía el reconocimiento de una arreglada conducta y reputación, así como de la pureza de oficios viles y limpieza de sangre. El pontevedrés Bernardo de la Gándara Barbeyto ejemplifica esta práctica. Este comerciante (o "mercader", tal y como aparece identificado en su licencia para pasar a Indias ${ }^{33}$ ), obtuvo despacho de hidalguía en 1722, en litisconsorcio junto a sus hermanos. Uno de ellos, Andrés, era ya por entonces familiar notario del Santo Oficio de Pontevedra. Ese mismo año, Bernardo obtuvo el nombramiento de familiar de la Inquisición, un cargo muy atractivo para un comerciante ya que le abría las puertas de la respetabilidad social ${ }^{34}$. Esta estima por los cargos del Santo Oficio se acentuaría a lo largo del siglo XVIII al proponerse que el recluta-

31. Aunque desconocemos exactamente cuántos de ellos ingresaron en dicha corporación podemos servirnos del trabajo de Juan Brombley, que recopila un listado de los hermanos veinticuatro de la archicofradía entre 1775 y 1787: hallamos la convivencia de aristócratas junto a grandes comerciantes como los hermanos Isidro y Joaquín Abarca (emparentados con el condado de San Isidro), Cayetano Fernández Maldonado o Domingo Millán de Acha. Bromley, Juan. "Hermanos 24 de la Archicofradía de la Santísima Veracruz de Lima entre los años 1775 y 1787". Revista del Instituto de Investigaciones Genealógicas, 1963, 13, pp. 137-154.

32. Los de actos positivos de nobleza en América han sido recopilados por Lira Montt. LiRA MonTt, Luis. "La prueba de hidalguía en el derecho indiano". Hidalguía, 1977, 140, pp. 77-83.

33. Expediente de información y licencia de pasajero a indias de Bernardo de la Gándara. Cádiz, 24 de diciembre de 1723. Archivo General de Indias [en adelante AGI], Contratación, 5473, N. 1, R. 147.

34. Información genealógica de Bernardo Gándara y Barbeyto, natural de Santa Eulalia de Gil y pretendiente a oficial del Santo Oficio (1722). AHN, Inquisición, 1403, exp. 7. 
miento del personal inquisitorial se efectuase solamente entre nobles y personas del mayor lustre ${ }^{35}$.

La organización de las milicias disciplinadas durante la segunda mitad del siglo XVIII tuvo una fuerte repercusión social. De hecho, a partir de los años sesenta encontramos un número considerable de grados militares entre los pretendientes a la hidalguía, con especial incidencia entre los comerciantes (vid. Apéndice). El servicio de armas que adquirió un gran aprecio social a través de estos cuerpos de milicias, unidades vitales para el plan de reforma del régimen defensivo americano. A pesar de que hasta 1793 no se estableció un reglamento definitivo para las milicias del Perú -siguiendo el modelo del dictado para la isla de Cuba de $1769^{36}$ - previamente, en la década de los años sesenta, el virrey Amat ya había sentado las bases sobre las que se asentarían las futuras milicias disciplinadas. Dentro del reglamento promulgado por el virrey se contemplaban dos capítulos especialmente atrayentes para los candidatos a la oficialidad: la reserva de los empleos de oficiales para las personas más condecoradas de las provincias (punto IV del Reglamento), es decir, para las más distinguidas; y el goce del fuero militar para la oficialidad mientras estén en los empleos (punto V) ${ }^{37}$. El colofón a estas graciosas concesiones fue la conversión del servicio en milicias en un auténtico puente al ennoblecimiento de iure accediendo a que todo oficial que hubiese servido en ellas "en calidad de tal ocho años sin intermisión, con aplicación, celo y conducta" fuese acreedor a la merced de hábito de las órdenes militares ${ }^{38}$.

Surgiría así una nueva vía de ennoblecimiento en la que la obtención de un grado como oficial permitiría a las clases dominantes americanas acentuar la distancia social existente con el resto de la población. De hecho, en ciudades como México y Caracas la designación de personas ajenas a los círculos aristocráticos locales como oficiales ocasionó serias disputas entre las autoridades y los cabildos, bastiones de la nobleza criolla ${ }^{39}$. En ambos casos el conflicto se centró en el malestar de la élite criolla por el nombramiento de peninsulares. En vista de los

35. Cerrillo Cruz, Gonzalo. Los familiares de la Inquisición española. 1. ${ }^{a}$ ed. Valladolid: Junta de Castilla y León, 2000, pp. 89-90.

36. MARChENA FERNÁNDEZ, Juan. Ejército y milicias en el mundo colonial americano. $1 .^{\mathrm{a}}$ ed. Madrid: MAPFRE, 1992, pp. 106-107.

37. Copia del Reglamento de Milicias del Perú dictado por Don Manuel de Amat. Lima, 31 de agosto de 1766. Archivo General de Simancas [en adelante AGS], Secretaría de Guerra, 7128-2.

38. En España se resuelve mediante la Real Orden de 30 de mayo de 1767. Novísima Recopilación. Lib. VI, Tít. IV, 1. XII. En América esta disposición estuvo vigente a partir de la Real Orden de Aranjuez, 15 de abril de 1769 prescribiendo los periodos de servicios necesarios para obtener una merced de hábito en los distintos cuerpos de tropa: cuatro años de oficial en las tropas veteranas, ocho en las milicias, etc. KONETZKE. Richard. Colección de documentos para la historia de la formación social de Hispanoamérica, 1493-1810. Madrid: CSIC, 1962, III (1), p. 359.

39. Nombramientos de José de Asso y Otal como coronel del regimiento de milicias provincial de México en 1766 y de Sebastián Miranda como oficial del batallón de blancos de Caracas en 1769. Navarro García, Luis. "Nobleza criolla y milicia en México, 1766". Temas Americanistas, 2002, 15, pp. 
argumentos esgrimidos por los criollos podemos comprobar cómo la causa principal de estos conflictos no era el rechazo frontal del contingente europeo en su conjunto sino solo de aquellos advenedizos que accedían a los empleos de honor -a los que, por supuesto, la élite se creía acreedora por antigüedad y prosapia- y cuya condición de iguales era rechazada por la nobleza local ${ }^{40}$. De este modo, las jerarquías de las milicias comenzaron a reproducir la estructura social. En las zonas rurales peruanas eran un claro reflejo de la hacienda (es decir, el amo era el coronel, sus hijos capitanes, los capataces sargentos y los peones la tropa) mientras que en las ciudades era el patriciado local el que copaba la alta oficialidad, es decir, la nobleza titulada, los cabildantes, los miembros del consulado, los funcionarios de la Real Hacienda, etc. ${ }^{41}$.

En cuanto al prestigio de las diferentes armas de milicias no cabe duda de que la de caballería fue el cuerpo más estimado por la nobleza americana ya que indudablemente evocaba al équite o caballero. Este aprecio se incrementaría tras la oposición de la Corona, que tanto había insistido en la formación y adiestramiento de la nobleza en las armas y la equitación a través de las maestranzas de caballería, a que estas corporaciones se instalaran en los territorios ultramarinos al rechazar la petición de los hijosdalgo de la ciudad de México en el año de $1790^{42}$. Esta negativa convertiría el servicio en los regimientos de caballería en lo más similar que existiría en América a esas corporaciones nobiliarias.

Pero para otros muchos oficiales el interés por servir en estos cuerpos no se limitaba a una mera cuestión de prestigio. La Corona, interesada en implicar a toda la estructura social indiana en la estrategia defensiva, procuró incentivar la participación de las élites concediendo el fuero militar con todos sus privilegios y exenciones fiscales. En el Perú estas prerrogativas atrajeron especialmente a los comerciantes, ya que mientras para unos las milicias eran un vehículo de ascenso social para otros servían como recurso para evadir sus responsabilidades ante los acreedores $^{43}$. El abuso de dicha prerrogativa por parte de los comerciantes llegó

64-72; Quintero, Inés. "Los nobles de Caracas y la Independencia de Venezuela". Anuario de Estudios Americanos, julio-diciembre 2007, 64-2, p. 213.

40. En México se argumentaba que, como peninsular que era, Asso y Otal no solo no pertenecía a la nobleza del país sino que tampoco "se había hermanado con él", es decir, que la nobleza criolla no le reconocía como igual. En cambio, en Caracas Sebastián Miranda era descalificado principalmente por los oficios bajos que había ejercido como mercader público y antes cajonero (tendero). NAVARRO García, Luis. “Nobleza criolla...”, p. 29; QuinTERo, Inés. "Los nobles de Caracas...”, p. 213.

41. MARChENA FERNÁNDEZ, Juan. "Ejército y cambio social en la América de fines del XVIII". En VV. AA. La América española en la Época de las Luces: tradición-innovación-representaciones: (Coloquio franco-español, Maison des Pays Ibériques. Burdeos, 18-20 septiembre 1986). 1. ${ }^{a}$ ed. Madrid: Ediciones de Cultura Hispánica, 1988, p. 88.

42. KonetzKe, Richard. Colección de documentos..., III (2), pp. 677-682.

43. PARRÓn SALAS, Carmen. "Nuevas perspectivas del Perú colonial y su transición al mundo contemporáneo". En Vila Vilar, Enriqueta y Kuethe, Allan J. (eds.). Relaciones de poder y comercio colonial, 1. ${ }^{a}$ ed. Sevilla: Escuela de Estudios Hispano-Americanos, 1999, pp. 206-208 y "Burguesía mer- 
a tal extremo que en 1802 la Corona se vio obligada a advertir que la inmunidad del fuero militar no comprendía las causas mercantiles ${ }^{44}$.

Entre los pretendientes se constata además una estrecha relación de los grandes comerciantes con el servicio en la milicia. Así, por ejemplo, de siete individuos que ocuparon cargos directivos en el Consulado (Vid. Tabla 2), cuatro de ellos desempeñaron algún grado en las milicias. Juan Antonio de Bustamante Quijano, en el batallón de comercio de Lima; Cayetano Fernández Maldonado, en el regimiento de dragones de Carabayllo; Isidro Abarca, al igual que su hermano Joaquín, entró en el distinguido regimiento de la nobleza de Lima, comandado por el propio virrey; y Manuel de Gorbea, en el de las milicias disciplinadas de Chancay. Teniendo en cuenta que todos ellos habían ejercido como oficiales tiempo antes de dirigir la institución mercantil parece probable que la distinción social y la condición de aforados que reportaba el grado militar contribuyesen a la consolidación de su reputación como comerciantes respetados ${ }^{45}$.

Esta apetencia desmedida por los empleos de milicias por parte de los comerciantes alcanzó extremos grotescos, tal y como retrata Humboldt quien, con cierta ironía, afirmaba que

cuando se recorre la cordillera de los Andes, admira ver en las pequeñas ciudades de provincias situadas en el lomo de las sierras, transformados todos los negociantes en coroneles, capitanes y sargentos mayores de milicias... Algunas veces se ven oficiales de milicias con grandes uniformes y condecorados de la Real Orden de Carlos III, sentados con suma gravedad en sus tiendas y ocupándose en las mayores menudencias concernientes a la venta de sus mercancías; mezcla singular de vanidad y de sencillez de costumbres... ${ }^{46}$.

cantil y estado colonial. Los comerciantes de Lima (1778-1821)". En ENCISO Recio, Luis Miguel (coord.). La burguesía española en la Edad Moderna: Actas del Congreso Internacional celebrado en Madrid y Soria los dias 16 a 18 de 1991. 1. ${ }^{a}$ ed. Valladolid: Universidad de Valladolid, 1996, II, pp. 718-719.

44. MARChena Fernández, Juan. Ejército y milicias..., p. 109.

45. Si bien los cónsules Diego Sáenz de Tejada y Manuel Hilario de la Torre Quirós no fueron oficiales de milicias, sí ocuparon corregimientos en Indias, por cuyo desempeño se les daba el tratamiento honorífico de general incluso tras abandonar el cargo. AGN, Notarial, Valentín de Torres Preciado, prot. 1066, ff. 704r-708r; AGS, Dirección General del Tesoro, Invent. 24, 182-519. GuARDA GEYwiTZ, Gabriel, La sociedad en Chile austral antes de la colonización alemana, 1645-1845, $1 .^{\mathrm{a}} \mathrm{ed}$. Santiago: Universidad Católica de Chile, 1979, p. 489.

46. Humboldt, Alejandro de. Ensayo político sobre el reino de la Nueva España (estudio preliminar, revisión de texto, cotejos, notas y anexos de Juan Antonio Ortega y Medina). 2. ${ }^{a}$ ed. México: Porrúa, 1973, p. 558. 
JORGE PÉREZ LEÓN

EL ÉXITO SOCIAL ENTRE LOS EMIGRANTES PENINSULARES EN EL PERÚ

TABLA 2. COMERCIANTES Y MILICIAS

\begin{tabular}{|l|l|l|}
\hline \multicolumn{1}{|c|}{ COMERCIANTE } & \multicolumn{1}{|c|}{ CARGO CONSULADO } & \multicolumn{1}{c|}{ GRADO DE MILICIAS } \\
\hline $\begin{array}{l}\text { Manuel Hilario de la Torre } \\
\text { Quirós }\end{array}$ & Prior (1756-1758) & - \\
\hline $\begin{array}{l}\text { Juan Antonio de } \\
\text { Bustamante Quijano }\end{array}$ & Prior (1767-1768) & $\begin{array}{l}\text { Capitán del batallón de } \\
\text { comercio de Lima } \\
\text { (c. 1758) }\end{array}$ \\
\hline Diego Sáenz de Tejada & Cónsul (1778-1782) & - \\
\hline Isidro Abarca & Prior (1785-1786; 1789-1790 y & $\begin{array}{l}\text { Alférez del regimiento de } \\
\text { nobleza de Lima } \\
\text { (c. 1776) }\end{array}$ \\
\hline $\begin{array}{l}\text { Francisco Álvarez } \\
\text { Calderón }\end{array}$ & Cónsul (1780) & - \\
\hline $\begin{array}{l}\text { Cayetano Fernández } \\
\text { Maldonado }\end{array}$ & Cónsul (1789-1790 y 1791-1792) & $\begin{array}{l}\text { Capitán de Dragones del } \\
\text { Regimiento de Milicias } \\
\text { de Carabayllo (c. 1790) }\end{array}$ \\
\hline Manuel Gorbea y Vadillo & Prior (1819 y 1820) & $\begin{array}{l}\text { Capitán de las milicias de } \\
\text { Chancay (c. 1788) }\end{array}$ \\
\hline
\end{tabular}

Fuente: Elaboración propia basada en MendiBuru, Manuel de. Diccionario histórico-biográfico... (1. ${ }^{a}$ ed.), t. VIII, pp. 449-451. Los cargos de milicias proceden de: ARChV, Sala Hijosdalgo, C. 956-29; AHN, Órdenes, Santiago, exp. 10; AGS, Secretaría de Guerra, 7127-20 y 7115-15.

Por último, hemos de considerar los oficios más prestigiosos a los que se podía aspirar en una localidad: los oficios de gobierno y justicia de los cabildos. Entre los individuos estudiados encontramos varios que ocuparon alcaldías ordinarias, unas magistraturas de carácter anual formadas por dos jueces elegidos por los regidores de entre los vecinos más distinguidos de la ciudad. Al examinar su trayectoria y antecedentes observamos que cuatro de los seis peninsulares obtuvieron estos nombramientos pocos años después de contraer matrimonio con criollas ilustres (Vid. Apéndice). En Lima, los hermanos Isidro y Joaquín Abarca, casados respectivamente con la condesa de San Isidro (en 1774) y la hija de esta (en 1779), fueron nombrados alcaldes en los años de 1779 y 1783 respectivamente. El encartado Francisco de Ocharán y Mollinedo, alcalde ordinario de Lima en 1780, había contraído matrimonio cinco años antes con la notable limeña Mariana Carrillo de Córdoba y Sancho-Dávila. En Arequipa, al alavés Juan José Arechavala, administrador de la renta de correos, accedió al cargo en 1780, cinco años después de casar con M. ${ }^{a}$ Gertrudis Aranibar. Se constata por lo tanto una clara correspondencia entre sus enlaces y la elección para estos cargos. Esto demuestra que la unión con criollas notables y, por ende, con su familia era una cuestión decisiva a la hora de que las elites locales, representadas por los regidores, los considerasen adecuados para ejercer dichas magistraturas. 


\section{CULMinACiÓN DEL ÉXITO SOCIAL: EL ENNOBLECIMIENTO}

En una sociedad tan deseosa de reconocimiento social como la peruana, una trayectoria exitosa no se vería culminada hasta la obtención de una distinción que reforzase la idea de la posesión -de iure- de requisitos sociales tan estimados como la hidalguía, la limpieza de sangre o la pureza de oficios, que aseguraban la aceptación como un igual por parte de la élite. En ese sentido, la consecución de un título nobiliario o de un hábito de alguna de las órdenes militares constituía una prueba incontestable de la posesión de dichos requisitos, demostrando además que el agraciado gozaba de la aprobación regia. Tampoco podemos olvidar que para obtener alguna de estas mercedes el candidato debía disponer de un desahogado respaldo económico o de destacados servicios a la Corona ${ }^{47}$.

Habida cuenta de la reducida presencia de nobles titulados entre los sujetos estudiados nos centraremos en aquellos que obtuvieron mercedes de alguna de las órdenes militares y de la orden de Carlos III ${ }^{48}$. Como sabemos, todo aquel que desease cruzarse como caballero en una de estas órdenes debía ostentar una lustrosa ascendencia demostrando su hidalguía, limpieza de sangre y de oficios viles por los cuatro costados. La demostración de tales requisitos y la definitiva consecución de estas mercedes exigía de un largo y costoso proceso, tal y como se refleja en la complejidad de los procedimientos e instancias implicadas en las concesiones ya que no solo afectaba al Consejo de Órdenes, encargado de concederlas, sino también a otros órganos de gobiernos como, por ejemplo, el Consejo de Estado o el Consejo de Indias que evaluaban los memoriales que se les remitían ${ }^{49}$.

A partir de las tres últimas décadas del siglo XVIII se aprecia un incremento de estas concesiones entre los pretendientes (Gráfica 1). Un total de 12 pretendientes

47. Sobre los requisitos para la concesión de títulos nobiliarios Vid. FeLICES DE LA FuENTE, M. ${ }^{\mathrm{a}}$ del Mar. La nueva nobleza titulada de España y América en el siglo XVIII (1701-1746). Entre el mérito y la venalidad. 1. ${ }^{a}$ ed. Almería: Universidad de Almería, 2012, pp. 45-55; MARURI Villanueva, Ramón. "De la vieja Montaña a la Nueva España: los caminos hacia la nobleza titulada (siglo XVIII)". En ARANDA PÉREZ,

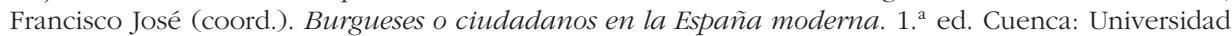
de Castilla-La Mancha, 2003, pp. 257-302 y "Poder con poder se paga: títulos nobiliarios beneficiados en Indias (1681-1821)". Revista de Indias, 2009, vol. LXIX, 246, pp. 207-240.

48. Solo dos de los pretendientes aquí estudiados llegaron a convertirse en nobles titulados. El montañés Isidro de Abarca Gutiérrez, conde consorte de San Isidro, y el asturiano Alonso González del Valle, vecino de Ica, marqués de Campo Ameno, título beneficiado a su favor por la catedral de Concepción de Chile bajo licencia del virrey Manso de Velasco. MARTínez MARTín, Carmen. "Linaje y nobleza del virrey don José Manso de Velasco, conde de Superunda". Revista Complutense de Historia de América, 2006, 32, p. 274. Maruri VillanueVA, Ramón. "Poder con poder...", p. 212.

49. Sobre los procedimientos y trámites administrativos de estas concesiones Vid. ÁlvarEZ-CoCA GonZÁLEZ, M. ${ }^{a}$ Jesús. "La concesión de hábitos de caballeros de la Órdenes Militares: procedimiento y reflejo documental (ss. XVI-XIX)». Cuadernos de Historia Moderna, 1993, 14, pp. 277-297. 
a la hidalguía en la Real Chancillería de Valladolid se cruzaron como caballeros de alguna de las órdenes de Santiago, Calatrava, Alcántara y la de Carlos III ${ }^{50}$.

Gráfica 1

HÁBITOS DE ÓRDENES MILITARES CONCEDIDOS A LOS PRETENDIENTES

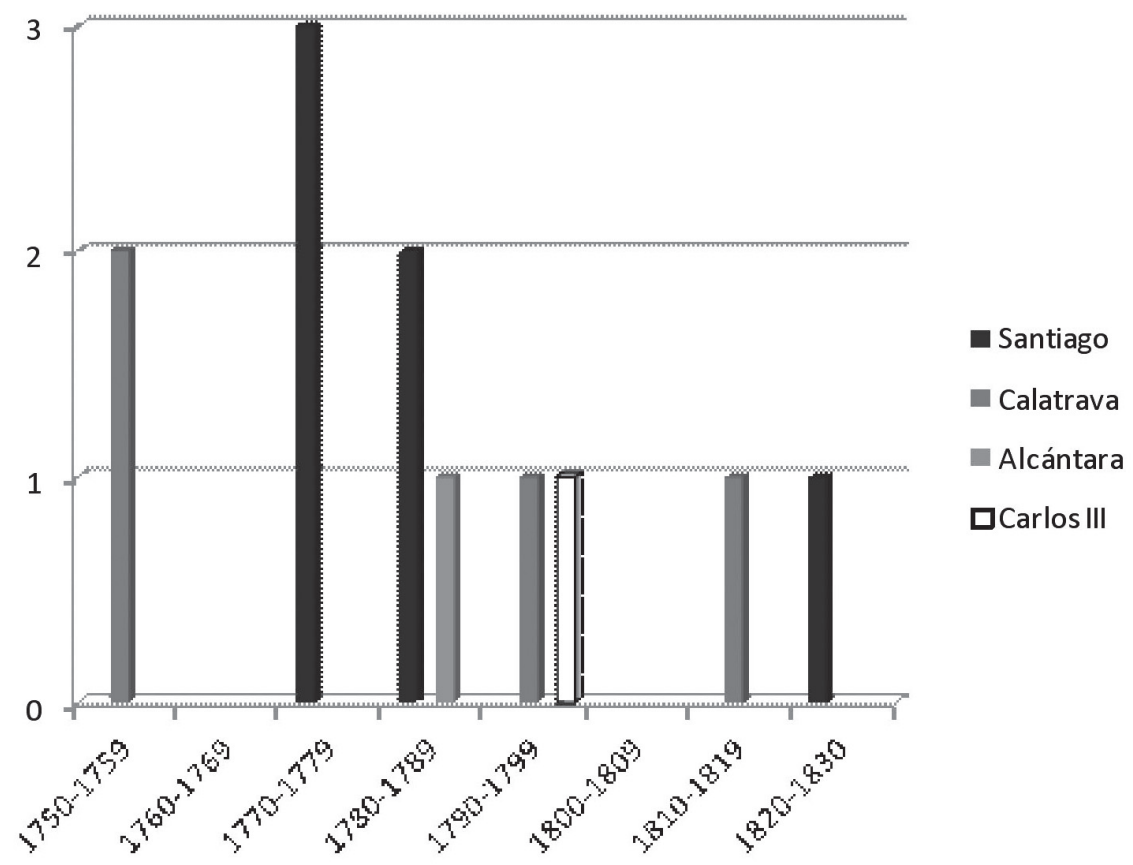

Fuente: Elaboración propia a partir de diversos expedientes. AHN, secciones Órdenes y Estado.

Hasta la década de los años setenta solo se cruzaron caballeros Simón Lavalle y la Bodega (1750) y Manuel Hilario de la Torre Quirós (1753), ambos en la orden de Calatrava. Es entre 1770 a 1800 cuando hallamos la mayoría de las concesiones de hábito con un total de ocho pretendientes (67\%). La influencia de la citada Real

50. Este porcentaje representa el $16,66 \%$ de los pretendientes (12 sobre un total de 72 pretendientes). En la orden de Santiago Isidro y Joaquín Abarca Gutiérrez (1776 y 1777 respectivamente), Diego Sáenz de Tejada (1781), Isidro y Simón Gutiérrez de Otero (1777 y 1787 respectivamente) y Martín Antonio de Aramburu y Echeverría (1830); en la de Calatrava encontramos a Simón de Lavalle y la Bodega (1750), Manuel Hilario de la Torre Quirós (1753), Juan José Martínez de Pinillos (1810) y Juan José de Arechavala e Ibarra (1790); en la de Alcántara a Diego Antonio de la Casa y Piedra (1789); y en la de Carlos III José Lucas de Gorbea y Vadillo (1796). 
Orden de Aranjuez de 15 de abril 1769, por la que los oficiales de los cuerpos de milicias que hubiesen servido durante ocho años de forma ininterrumpida podían solicitar un hábito de las cuatro órdenes militares (Santiago, Calatrava, Alcántara y Montesa), tuvo una influencia indiscutible. Esta disposición avivó el interés y la participación en los cuerpos de milicias por parte de los interesados en labrarse una buena reputación. De este modo la milicia se convirtió en una vía privilegiada para cruzarse como caballero. De nuevo, serían los comerciantes los que aprovecharían esta oportunidad, como los hermanos Isidro y Joaquín Abarca, alférez y subteniente del regimiento de la nobleza de Lima respectivamente, que en 1776 solicitarían sendos hábitos santiaguistas ${ }^{51}$. Precisamente ese mismo año Isidro contraería matrimonio con la condesa de San Isidro. Otro comerciante montañés, Diego Antonio de la Casa y Piedra, capitán de milicias españolas, obtendría el hábito de la orden de alcántara en 1789 tras alegar en su favor los nueve años de servicio como capitán y su participación en la guerra contra Inglaterra y en la extinción de la revuelta de Tupac Amaru ${ }^{52}$. Los funcionarios de la Corona tampoco renunciaron a esta opción de ennoblecimiento. Es el caso de Juan José de Arechavala, administrador de la renta de correos y antiguo alcalde ordinario de Arequipa, que en 1790 solicitó una merced de hábito como coronel agregado que era del regimiento de milicias de dicha ciudad ${ }^{33}$.

Diferente es el caso de la Real y Distinguida Orden de Carlos III, creada en 1771 y nacida con un espíritu de renovación, con la que se pretendía premiar las aspiraciones sociales de la nobleza de servicio. Villalba Pérez observa que de los 200 caballeros pensionados los más beneficiados fueron los militares, especialmente oficiales de la Marina, y los funcionarios, destacando los de Indias ${ }^{54}$. Un perfil que se corresponde perfectamente con el de José Lucas de Gorbea y Vadillo, fiscal de la audiencia de Lima, condecorado con la cruz de Carlos III en $1796^{55}$.

51. Pruebas para la concesión de hábito de Isidro Abarca (1776). AHN, Órdenes, Santiago, exp. 10; Pruebas para la concesión de hábito de Joaquín Abarca (1776). AHN, Órdenes, Datas Santiago, exp. 11.

52. Solicitud de merced de hábito de Diego de la Casa y Piedra, capitán de milicias de Lima (1789). AGS, Secretaría de Guerra, 7116-32.

53. Concesión de hábito de la orden de Calatrava a Juan José de Arechavala, coronel de milicias de Arequipa (1790). AGS, Secretaría de Guerra, 7117-14.

54. Villalba PÉREz, Enrique. "La Orden de Carlos III: ¿Nobleza reformada?”. En Coloquio internacional Carlos III y su siglo: actas. Madrid: Universidad Complutense de Madrid, 1990, II, pp. 676-677.

55. Expediente de pruebas del caballero de la orden de Carlos III, José Lucas de Gorbea y Vadillo. AHN, Estado-Carlos III, exp. 983. 


\section{TRASCENDENCIA SOCIAL Y PERPETUACIÓN DE LA MEMORIA}

Como hemos podido comprobar, labrarse un nombre y una buena reputación era una larga y ardua tarea, por lo que no resulta extraño que fuesen los descendientes de estos peninsulares quienes culminasen el ascenso social iniciado por sus progenitores. La presencia de los hijos de los pretendientes en el cabildo limeño supone un indicio de esta ascendente progresión familiar. Como regidores perpetuos encontramos a José Antonio de Lavalle y Cortés, hijo del encartado Simón de Lavalle y la Bodega, cuya plaza pasaría a su hijo Juan Bautista de Lavalle y Zugasti; a Juan de Berindoaga y Palomares, hijo del navarro Juan Félix de Berindoaga Irazoqui; a Francisco Álvarez Calderón, de igual nombre que su padre montañés; y a Matías de la Torre y Tagle, hijo del también montañés Manuel Hilario de la Torre Quirós y la limeña Águeda de Tagle y Bracho ${ }^{56}$.

En casos excepcionales la persistente búsqueda del honor nobiliario sería premiada con la concesión de un título nobiliario en generaciones posteriores. Buen exponente de este triunfo social se halla representado por el trujillano José Antonio Lavalle y Cortés, acaudalado comerciante y naviero, caballero de la orden de Santiago y I conde de Premio Real ${ }^{57}$. Otro personaje de renombre fue Juan de Berindoaga y Palomares, abogado de la Real audiencia y vizconde de San Donás ${ }^{58}$.

La emergencia de estas familias en el panorama social peruano también se observa a través de su papel protagonista durante la fase emancipadora. Juan de Berindoaga y Palomares abrazaría inicialmente la causa de la emancipación, ejerciendo incluso como ministro de gobierno y de relaciones exteriores del gobierno republicano en 1823, pero su comportamiento errático le costaría la enemistad de Bolívar y, finalmente, la condena a muerte en $1826^{59}$. Por el contrario, Tomás de la Casa y Piedra García, hijo de Diego Antonio de la Casa y Piedra, ocuparía un lugar prominente en las filas realistas. Diputado provincial por Lima en las Cortes en 1814 y caballerizo mayor del virrey Pezuela firmaría, junto a otros notables, un memorial para que el virrey se aviniera a negociar la paz con San Martín. Tras ejercer el cargo de alcalde ordinario de Lima en 1819-20 moriría en el sitio de El Callao en $1825^{60}$.

56. Vid. Lohmann Villena, Guillermo. Los regidores perpetuos del cabildo de Lima (1535-1821). Sevilla: Diputación Provincial de Sevilla, 1983, vol. II.

57. Sobre la vida del conde de Premio Real Vid. MazzeO, Cristina Ana. El Comercio Libre...

58. Lohmann Villena, Guillermo. Los regidores perpetuos..., II, pp. 66-67. El vizcondado de San Donás no era un título nobiliario de origen castellano sino flamenco, heredado de su madre, Josefa de Palomares y Salazar. PATrón Boylan, Paul. Linaje, dote y poder..., p. 29.

59. LOHMANn Villena, Guillermo. Los regidores perpetuos..., II, p. 67.

60. Mendiburu, Manuel de. Diccionario histórico-biográfico del Perú, $2^{\mathrm{a}}$ ed. Lima: Imprenta de J. Francisco Solís, 1931, T. IV, p. 39. 
El papel de las hijas dentro de la promoción social de la familia también sería importante, jugando un papel fundamental en la articulación de las relaciones sociales a través de los enlaces matrimoniales. Aunque la consecución de un pretendiente idóneo podía suponer un gran esfuerzo económico a la familia de la novia, estos desembolsos, bien invertidos, podían rentabilizarse económica y socialmente. Juan Agustín Frade y Sierra, oficial de la Caja Real de Lima, logró emparentar con una de las familias de más alta alcurnia de Lima tras casar a su hija mayor, M. ${ }^{a}$ Josefa Rudesinda, nada menos que con Juan José Vázquez de Acuña Román Irigoyen Menacho y Zorrilla, conde de la Vega del Ren, al que le entregó en concepto de dote 37.963 pesos y 4 reales $^{61}$. Circunstancias similares concurren en el caso del comerciante riojano Pedro Moreno, que casaría a su hija M. ${ }^{a}$ Manuela con José Pío García - un rico minero que usaría el título de conde de Castañeda de los Lamos aunque sin tomar posesión del mismo ${ }^{62}-$ a quien entregó en concepto de dote la cantidad de 58.648 pesos y 7 reales. A la hija menor, M. ${ }^{a}$ Rosa de Santo Domingo, casada con el comerciante montañés José Correa, la dotó con 61.093 $\operatorname{pesos}^{63}$. Sensiblemente inferior sería la dote entregada por el comerciante Martín Antonio de Aramburu Echeverría a cada una de sus cuatro hijas, valorada alrededor de 300.000 reales de vellón (cerca de 15.000 pesos fuertes) ${ }^{64}$.

La búsqueda del reconocimiento y la honorabilidad social es una cuestión de tanta importancia que trasciende la propia muerte física de los pretendientes. Los testamentos dan fiel testimonio de esto ya que permitían a los otorgantes no solo transferir sus bienes sino también su "herencia inmaterial", es decir, todo aquello que recuerde su éxito económico y social. Para ello se sirvieron de diversas herramientas como los legados y, sobre todo, las fundaciones de obras pías (capellanías, patronatos) y la institución de mayorazgos, muchos de ellos ordenados a la hora de testar, convirtiéndose en medios fundamentales para conservar la memoria del fundador en la Tierra y, en última instancia, para consolidar la idea de continuidad como pater familias de un nuevo linaje.

A lo largo de su estancia en América muchos de estos peninsulares habían contribuido al auxilio de sus familiares con el envío periódico de auxilios económicos a España, unas remesas que contribuían a aliviar, cuando no a mejorar, su

61. Testamento de Juan Agustín Frade y Sierra. Lima, 12 de septiembre de 1766. AGN, Notarial, Gregorio González de Mendoza, prot. 513, ff. 178-186.

62. Según las Tradiciones Peruanas de Ricardo Palma, José Pío García adquirió el título nobiliario de forma rocambolesca tras vencer a los gallos al conde legítimo, Manuel Díaz de Requejo, aunque la Corona nunca reconoció dicho traspaso. HAMPE MARTínez, Teodoro. "Las Tradiciones Peruanas y el imaginario de la nobleza titulada del virreinato". Revista de Indias, 2001, LXI, 222, pp. 343-344.

63. Recibo dotal de José García Pío a Manuela Moreno Ramírez. Lima, 6 de julio de 1796. AGN, Notarial, José de Aizcorbe, prot. 34, ff. 172r-181r. Recibo dotal de José Correa a Rosa Moreno y Ramírez. Lima, 23 de marzo de 1798. AGN, Notarial, José de Aizcorbe, prot. 35, ff. 77v-83v.

64. Testamento de Martín Antonio de Aramburu Echeverría. Cádiz, 22 de junio de 1838. Archivo Histórico Provincial de Cádiz [en adelante AHPC], Protocolos Notariales Cádiz, Juan Manuel Martínez, prot. 484 , f. 338 r. 
precaria situación. Por ejemplo, Francisco Lombera declaró que había "adquirido el caudal con mi industria y trabajo en estos remotos reinos sin auxilio, gasto ni fomento de mis padres a quienes antes he socorrido y mantenido" ${ }^{65}$.

La llamada de familiares por parte de los indianos para que les asistiesen en América también debe interpretarse como una forma de socorro ya que, al acoger y sustentar a los parientes llamados, el núcleo familiar tenía una boca menos que alimentar. Así lo hizo el montañés Manuel Antonio de la Torre Caviedes cuando legó 1.000 pesos a su sobrino Joaquín Fernández de la Torre, en muestra del buen afecto y amor que le tenía "por haberlo fomentado desde tierna edad, manejándose con honradez" ${ }^{66}$. Otros velaban por el futuro de sus protegidos procurándoles cargos y grados. El gijonés Toribio Menéndez Valdés remitió en 1773 la cantidad de 12.000 pesos al comerciante gaditano Marcelino Martínez Junquera con el fin de que consiguiera una capitanía de infantería para su sobrino José Antonio de Hevia, hijo de su hermana María Catalina ${ }^{67}$. El vizcaíno Francisco Julián Ochoa de Berrio, de estado soltero, dispuso que sus albaceas atendiesen y fomentasen a sus sobrinos Agustín y Manuel Plácido de Berriozábal, el primero residente en Lima y el segundo en Madrid, "hasta que logren establecerse con su carrera respectiva" "68. Por su parte, debido a sus problemas de salud, el oficial real Juan Agustín de Frade y Sierra en 1759 delegó sus funciones como factor de la Caja Real de Lima, como no podía ser de otro modo, en su sobrino Cristóbal Francisco Rodríguez (de Frade) ${ }^{69}$.

En algunos casos, su calidad de benefactores les permitía incluso intervenir en los asuntos familiares, condicionando el apoyo económico al cumplimiento de sus deseos. El riosellano Fernando de Buergo y Popado revocaría una disposición testamentaria de sus padres favorable a su hermana Francisca, por la que la conce-

65. Testamento de Francisco Lombera. Lima, 25 de febrero de 1775. AGN, Notarial, Valentín de Torres Preciado, prot. 1066, f. 677v.

66. Testamento de Manuel Antonio de la Torre. Lima, 7 de septiembre de 1816. AGN, Notarial, Ignacio Ayllón y Salazar, prot. 27, f. 1459v.

67. Testamento de Toribio Menéndez de Valdés. Lima, 11 de junio de 1774. AGN, Notarial, Valentín de Torres Preciado, prot. 1071, f. 168r.

68. Testamento de Francisco Julián de Berrio. Cádiz, 22 de agosto de 1800. AHPC, Protocolos Notariales Cádiz, Manuel Sáenz, prot. 412, f. 662r. Manuel Plácido Berriozábal y Beitia desarrolló una exitosa carrera burocrática. Fue oidor de las Audiencias de Cuzco y Charcas, alcalde del Crimen en la de Lima y, finalmente, ministro togado del Consejo y de la Cámara del Consejo de Indias. Casó con M. ${ }^{a}$ Francisca Álvarez de Foronda, cuarta condesa de Vallehermoso, y fue nombrado caballero de Carlos III. Lohmann Villena, Guillermo. Los ministros de la Audiencia de Lima..., p. 13. Este cuidado fomento de los sobrinos es lo que Imízcoz Beunza denomina "inversión educativa", es decir, los costos del proceso de formación del sujeto hasta su colocación en algún puesto de la administración. IMízcoz Beunza, José $\mathrm{M}^{\mathrm{a}}$. "El patrocinio familiar. Parentela, educación y promoción de las élites vasco-navarras en la monarquía borbónica". En CHACón Jiménez, Francisco y Hernández Franco, Juan (eds.). Familia, poderosos y oligarquías. 1. a ed. Murcia: Universidad de Murcia, 2001, pp. 107-108.

69. Testamento de Juan Agustín Frade y Sierra. Lima, 12 de septiembre de 1766. AGN, Notarial, Gregorio González de Mendoza, prot. 513, f. 184v. 
dían como dote una cuarta parte de los socorros remitidos por el propio Fernando a España, debido a que esta había casado "contra su gusto [de Fernando] con Alonso de Herrera y haber sido la dicha Francisca desobediente a sus padres ${ }^{70}$.

$\mathrm{Y}$ es que, junto al genuino deseo de asistir a los parientes menos favorecidos, no se puede negar que, consciente o inconscientemente, estos auxilios permitían al testador hacer gala de su prosperidad y desprendimiento. A la hora de testar, los caudales y bienes acumulados tras años de trabajo se convertían en legados o rentas que podían sustentar fundaciones y obras pías con una utilidad tan material para los vivos como trascendente para el difunto. Esta clase de iniciativas sería lo que Langue denomina como "inversiones sociales" ${ }^{71}$. Así, mientras que las personas designadas como herederas o legatarias obtenían una fuente de rentas, el testador buscaba alcanzar fines más elevados como la salvación de su alma y la perpetuación de su memoria entre los vivos. Estas ayudas podían llegar en forma de legados como en el caso de Fernando Antonio de Cevallos, quien dejó dispuesto que se remitiesen al valle de Toranzo 4.000 pesos para repartirlos entre sus parientes más pobres e inmediatos ${ }^{72}$. Y es que las obras de caridad no eran simplemente un instrumento de piedad sino también una valiosa herramienta de propaganda social en aquellos lugares donde el otorgante pudiera ser reconocido. Domingo Millán de Acha Urruchi dispuso que se repartiesen 1.500 pesos en diversas obras en Lima (1.000 pesos para el Hospital de la Caridad y niños expósitos y otros 500 para los pobres vergonzantes) y otros 8.000 reales en Sevilla donde vivía su esposa Gertrudis Salvadora de Urruchi (para los hospitales más necesitados y los pobres vergonzantes a razón de 4.000 cada uno) ${ }^{73}$. Mucho más preciso fue Toribio Menéndez Valdés, quien a la hora asistir a los pobres, puso especial cuidado en que estos siempre fuesen "gente blanca", expresando con ello su visión y forma de pensar ${ }^{74}$.

La huella de su prosperidad también puede rastrearse en sus lugares de origen, en su "patria chica". Por ejemplo, el asturiano Fernando de Buergo Popado

70. Poder notarial otorgado conjuntamente por Fernando y José de Buergo Popado para revocar clausula del testamento paterno. Lima, 15 de febrero de 1737. AGN, Notarial, Francisco Estacio Meléndez, prot. 353, ff. 174r-175v.

71. LANGuE, Frédérique. "Las élites en América española, actitudes y mentalidades". Boletín Americanista, 1992-1993, 42-43, p. 131. Tampoco podemos olvidar que la vida del consulado de comercio estaba impregnada de una fuerte religiosidad, siendo las limosnas y las fundaciones de obras pías algunas de sus manifestaciones más importantes. PARRÓn SALAS, Carmen. "Religiosidad y finanzas en el consulado de Lima, 1778-1821". Hispania Sacra, 1992, 44, pp. 590-597.

72. Testamento de Fernando Antonio de Cevallos otorgado por Domingo de Bustamante y Benavides en virtud de poder para testar. Arequipa, 2 de junio de 1759. Archivo Regional de Arequipa [en adelante ARA], Notarial, Bernardo Gutiérrez, prot. 349, Cuadernillo 3, f. 207r.

73. Poder para testar de Domingo Millán de Acha. Lima, 16 de agosto de 1785. AGN, Notarial, Gervasio de Figueroa, prot. 458, ff. 442r-v

74. Testamento de Toribio Menéndez de Valdés. Lima, 11 de junio de 1774. AGN, Notarial, Valentín de Torres Preciado, prot. 1071, ff. 159r. 
dispuso la fundación de dos aniversarios de misas o patronatos de legos en su Ribadesella natal, cuyas rentas recaerían en sus hermanos. El primero, de 10.000 pesos de principal, en la Ermita de Nuestra Señora de Guía, en la barra de entrada de la villa de Ribadesella, nombrando como patrón a su hermano Francisco y a los descendientes de este; mientras que el segundo, con solo 4.000 pesos de principal, recayó en su hermano Antonio de Buergo y sus descendientes ${ }^{75}$. Otro asturiano, Toribio Menéndez Valdés, ordenó la institución de un aniversario de misas o patronatos de legos en la villa de Gijón. Esta fundación contaba con un principal de 6.000 pesos fuertes a entregar a su hermana María Catalina, que debía imponerlos sobre bienes raíces a censo perpetuo e irredimible, nombrando como primer patrón a su sobrino Rafael de Hevia, tercer hijo de Catalina. Después de todos los parientes más inmediatos de dicho Rafael Toribio ordenaba que se eligiese por patrón al caballero más pobre de la villa de Gijón "y para saber cuál ha de ser este doy facultad al señor alcalde del estado noble de la villa de Gijón para que elija siete caballeros, los más pobres que le parecieren y fueren naturales de la dicha villa de Gijón...” ${ }^{76}$. De nuevo tenemos aquí toda una declaración de intenciones por parte de Toribio que pone de manifiesto un sentido de solidaridad netamente estamental, auxiliando a otros paisanos de extracción noble como él y, por lo tanto, personas de igual condición a quienes, a diferencia del testador, la fortuna no había sonreído.

La acción benefactora hacia los familiares y los lugares de origen en España era lógicamente más acusada entre los testadores solteros quienes, ante la falta de herederos forzosos en América, se sirvieron de su patrimonio como una inversión para promocionar y capitalizar socialmente su éxito económico. El caso del montañés Pascual Fernández de Linares resulta representativo ya que personifica el arquetipo del indiano exitoso retornado. Soltero y sin descendencia directa, regresó a España tras forjar una gran fortuna con el comercio y con el desempeño de diversos cargos en la administración peruana ${ }^{77}$. A su regreso se convertiría

75. Testamento de Fernando de Buergo Popado. Lima, 16 de mayo de 1739. AGN, Notarial, Francisco Estacio Meléndez, prot. 357, ff. 716r-717v.

76. Testamento de Toribio Menéndez de Valdés. Lima, 11 de junio de 1774. AGN, Notarial, Valentín de Torres Preciado, prot. 1071, ff. 169r-171r.

77. SAn CRISTÓbal, Evaristo. Apéndice al Diccionario Histórico-Biográfico del Perú. 1. a ed. Lima: Librería e Imprenta Gil, 1935, T. II, p. 129. Sobre la destitución como corregidor tenemos las actuaciones del marqués de Casaconcha, oidor de la audiencia de Lima, contra Pascual Fernández de Linares, corregidor de Lucanas, sobre excesos en el uso y empleo de azogues (1725) AGI, Escribanía, 566 C. El cese como corregidor de Lucanas también aparece mencionado en las diligencias conducidas por el procurador de Pascual Fernández de Linares en la misma petición presentada ante la Audiencia de la Casa de la Contratación tras ser rehabilitado en el cargo. Licencia e información de embarque de Pascual Fernández de Linares. Cádiz, diciembre de 1730. AGI, Contratación, 5478, N. 1, R. 21, ff. 6r. En sus Paisajes y ensayos Miguel de Unamuno dedica unas páginas a este afortunado indiano de quien dice que regresó a su Tudanca natal enriquecido "que cuando estuvo gobernando El Callao después del catástrofe de su ruina, en cuya confusión resultaron muchos bienes mostrencos y nuestro amigo 
en un gran benefactor de su Tudanca natal. En su testamento -previo a su salida hacia la Península- dispuso, entre otras obras pías, la construcción de una capilla, de una escuela y de un estudio de gramática; impuso rentas para dotes de niñas doncellas y alimento de estudiantes y para comprar bulas para pobres; además, fundó un aniversario de 24 misas cantadas al Santísimo y 130 misas rezadas que debían celebrarse anualmente para bien de su alma y las de sus antepasados ${ }^{78}$. Sin embargo la falta de sucesión directa le empujó destinar sus cuantiosos bienes a su sobrina Rosa García de la Cuesta, casada con Pedro Juan de la Cuesta, hermano del que sería posteriormente capitán general de Castilla La Vieja, Gregorio García de la Cuesta ${ }^{79}$.

El establecimiento de fundaciones y vínculos de carácter religioso en América o en España como capellanías, patronatos y aniversarios de misas, más allá de su significado religioso o espiritual, era una forma de vincular la propiedad y de proveerse de un signo de estatus ${ }^{80}$, permitiendo perpetuar la memoria de los fundadores. Aunque en la mayoría de los casos se trata de fundaciones post mortem, previstas en los testamentos, también encontramos excepcionalmente alguna fundada en vida, como el aniversario de misas o patronato de legos fundado en Viana del Bollo por el comerciante Cayetano Fernández Maldonado. En principio instituido en nombre de su tío el licenciado Victorio Fernández - del que Cayetano era albacea- al no ser suficientes los bienes del legado del tío difunto, este último aportó de su propio caudal 2.000 ducados de principal para que se impusiesen sobre fincas seguras (cantidad que remitió a su cuñado Juan Manuel de Sarriá Cárdenas en Cádiz) nombrando como primer patrón a su hermano Santiago, vecino de Viana, con la obligación de decir 20 misas por el alma del licenciado Victorio Fernández y por la de sus padres y abuelos así como por la del propio Cayetano, su mujer, hijos y descendientes ${ }^{81}$.

Las personas más acaudaladas trataron de fundar sus propios mayorazgos, fundaciones típicamente estamentales por las cuales una serie de bienes quedaban indisolublemente unidos a un único poseedor, con lo que se conservaba el lustre familiar y el estilo de vida acomodado ${ }^{82}$. Estos vínculos, que en origen eran derecho privativo de la nobleza, permitían transmitir el apellido del fundador lo

[Fernández de Linares], que no lo era, se aprovechó muy bien de ellos." UnAmuno, Miguel de. Obras Completas. Paisajes y ensayos. 1. ${ }^{a}$ ed. Madrid: Escelier, D.L, 1966, p. 524.

78. Testamento de Pascual Fernández de Linares. Lima, 25 [dañado] 1747. AGN, Notarial, Francisco Estacio Meléndez, prot. 375, f. 4v.

79. Unamuno, Miguel de. Obras Completas..., pp. 526-527.

80. MATEO PÉREZ, Armando. "La "fundación de patronatos": fuente para el estudio de una realidad espiritual, social y artística". En PORREs, Rosa (dir.). Aproximación metodológica a los protocolos notariales de Álava (Edad Moderna). 1. e ed. Bilbao: Universidad del País Vasco, 1996, p. 363.

81. Poder notarial otorgado por Cayetano Fernández Maldonado para fundar aniversario o patronato de legos. Lima, 3 de enero de 1774. AGN, Notarial, Francisco Luque, prot. 627, ff. 10r-12v.

82. LADD, Doris M. La nobleza mexicana en época de la Independencia, 1780-1826. 1. ${ }^{\mathrm{a}} \mathrm{ed}$. México: Fondo de Cultura Económica, 1984, p. 103. 
que, en consecuencia, reforzaba la idea de linaje. Manuel Hilario de la Torre Quirós instituyó el suyo en Lima. Constaba de dos haciendas, un aniversario, la casa de residencia familiar, la dote (estimada en 65.000 pesos) y los bienes gananciales de su esposa Águeda de Torre Tagle ${ }^{83}$. El importante capital que exigía su fundación no siempre estaba al alcance de todos los testadores. El asturiano Toribio Menéndez Valdés dejaría dispuesta la institución de un mayorazgo en Gijón con el remanente de su caudal. Consciente de que dicha cantidad podía ser insuficiente una vez descontadas las deudas y legados, dispuso que de no alcanzar los 4.000 pesos no se fundase dicho vínculo. En este caso, el corto remanente y la plata labrada había de entregarse a quien le correspondiese gozar del mencionado mayorazgo, usando de dichos bienes a su arbitrio, con la única obligación de que, el primer viernes después de su recibo, mandase decir por su intención siete misas rezadas y una misa cantada con su vigilia y responso poniendo una tumba y luces delante del altar de Nuestra Señora de los Dolores, que llaman de la Veracruz en la parroquia de la villa de Gijón, "mi patria" ${ }^{84}$.

\section{CONSIDERACIONES FINALES}

La búsqueda del éxito social por parte de los peninsulares exigió de diversas de estrategias de promoción social. En este trabajo solo hemos aportado unas breves pinceladas sobre algunas de ellas. No obstante, resulta evidente que la integración en la comunidad de residencia y la exteriorización de estatus -lo que, generalmente, implicaba el ennoblecimiento de iure- eran cuestiones fundamentales para acceder a ese éxito.

Ser admitido y respetado como un igual por los convecinos requería de considerables esfuerzos y desembolsos por parte de los aspirantes. Aunque el ennoblecimiento de iure (mediante despachos de hidalguía, hábitos de órdenes militares y títulos nobiliarios) sería la vía fundamental para conseguirlo no podemos olvidar la significación que tuvieron en este sentido otras estrategias. El matrimonio fue, sin duda, un instrumento fundamental no solo para afirmar su compromiso con la comunidad sino también para elevar el estatus social del contrayente. Buena prueba de ello es la elección de algunos pretendientes como alcaldes ordinarios poco después de contraer matrimonio, una muestra de la influencia que ejercía la institución matrimonial como estrategia de asimilación del esposo peninsular y como indicio de respetabilidad. En este sentido, no tenemos duda de que el matrimonio sirvió además como plataforma para aspiraciones más elevadas, que serían debidamente respaldadas por la familia política. Por el contrario, entre los solteros estudiados no se constatan semejantes anhelos de elevación de su estatus

83. Turiso Sebastián, Jesús. Comerciantes españoles..., pp. 179-180.

84. Testamento de Toribio Menéndez de Valdés. Lima, 11 de junio de 1774. AGN, Notarial, Valentín de Torres Preciado, prot. 1071, f. 172v. 
personal, al menos durante su estancia en Perú. Sin embargo, la mayoría de ellos, con descendencia o sin ella, procuran perpetuar su memoria beneficiando a familiares y parientes en España por medio de legados y obras pías.

Pero, dentro de esta carrera por la respetabilidad, el matrimonio sería solamente el principio de un largo camino. El deseo convertirse en personas reconocidas y respetadas condujo a muchos peninsulares a participar en corporaciones como las cofradías, el Santo Oficio o los cabildos, lugares de sociabilidad que no solo proporcionaban prestigio sino que además creaban nuevos vínculos de relación. Como no podía ser de otro modo, la culminación de los procesos de acumulación de estatus personal sería el ennoblecimiento de iure, bien mediante la solicitud de ejecutorias de hidalguía en las Chancillerías peninsulares, bien a través de mercedes nobiliarias como hábitos de las órdenes militares o títulos nobiliarios. En este sentido hemos de destacar la influencia del servicio en las milicias disciplinadas en la concesión de hábitos de órdenes militares, lo que convirtió estos cuerpos en una vía de acceso de comerciantes a tales distinciones. Como se puede observar en el apéndice final, estas estrategias se desarrollaban generalmente en el periodo de unos pocos años, a lo sumo una década, revelando unos vertiginosos procesos de acumulación de estatus.

La descendencia serviría, en cierto modo, para avanzar en este ascenso social. La reproducción de las estrategias seguidas por los progenitores, la promoción de los hijos a cargos y honores más elevados y el establecimiento de nuevas alianzas matrimoniales contribuirían a consolidar la posición de la familia en la sociedad peruana. Finalmente, el uso de legados y fundaciones como medio de la trascendencia social post mortem resulta una cuestión de sumo interés. Detrás de tales actos descubrimos que no solo existe un sincero ánimo de beneficiar y dar sustento a parientes y paisanos sino que además poseen un marcado contenido simbólico, cuya finalidad principal es la de perpetuar el éxito económico y social de los testadores en la memoria de los destinatarios. 
Torre Quirós,

Manuel Hilario de la (Cm)

Gouzález del Valle,

Alouso

Lavalle San MartinBodes
Salazar Cuadra,

Simón de (Cm-Ad)

Frade y Sierri,

Jun Agustin (Ad)

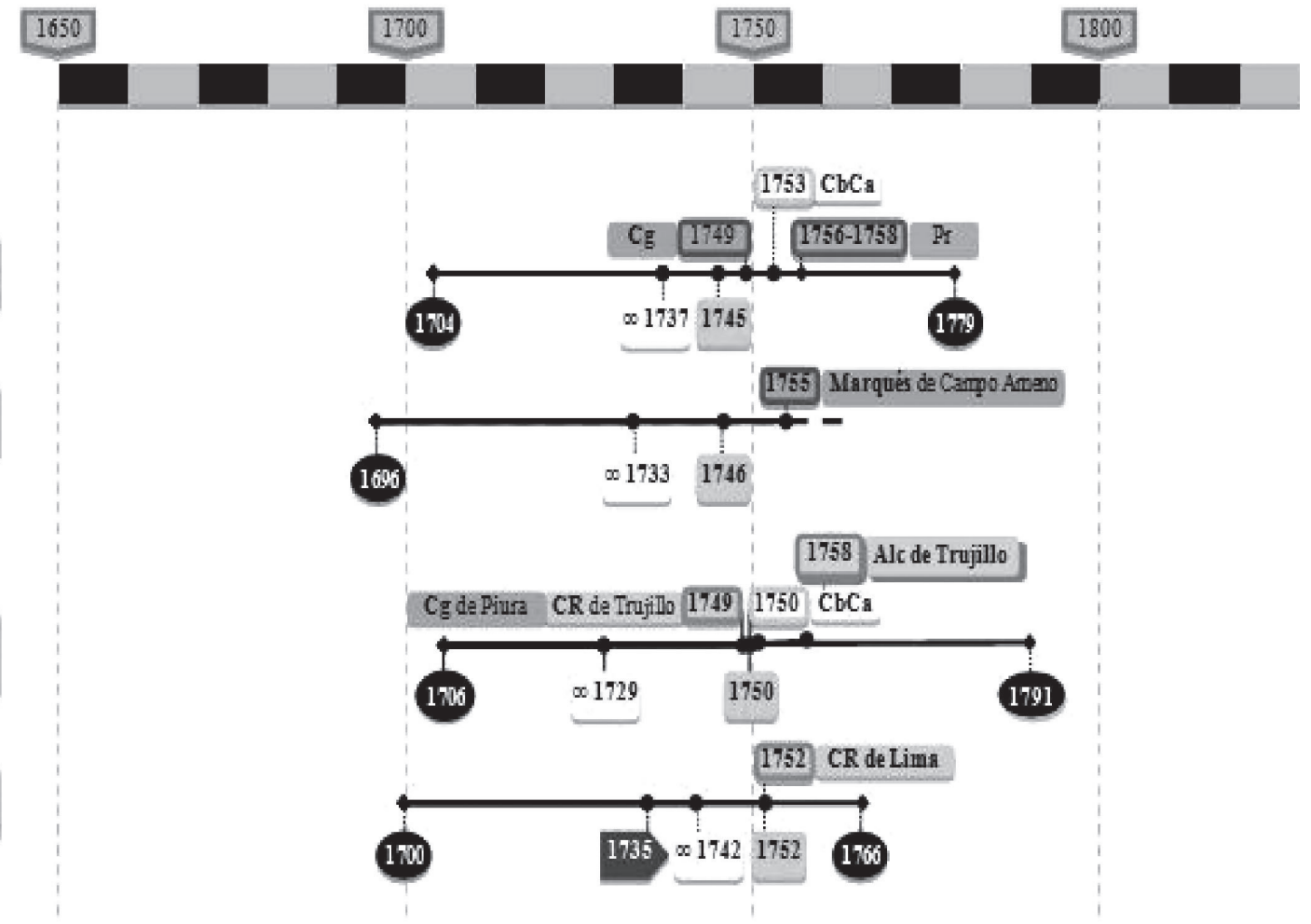




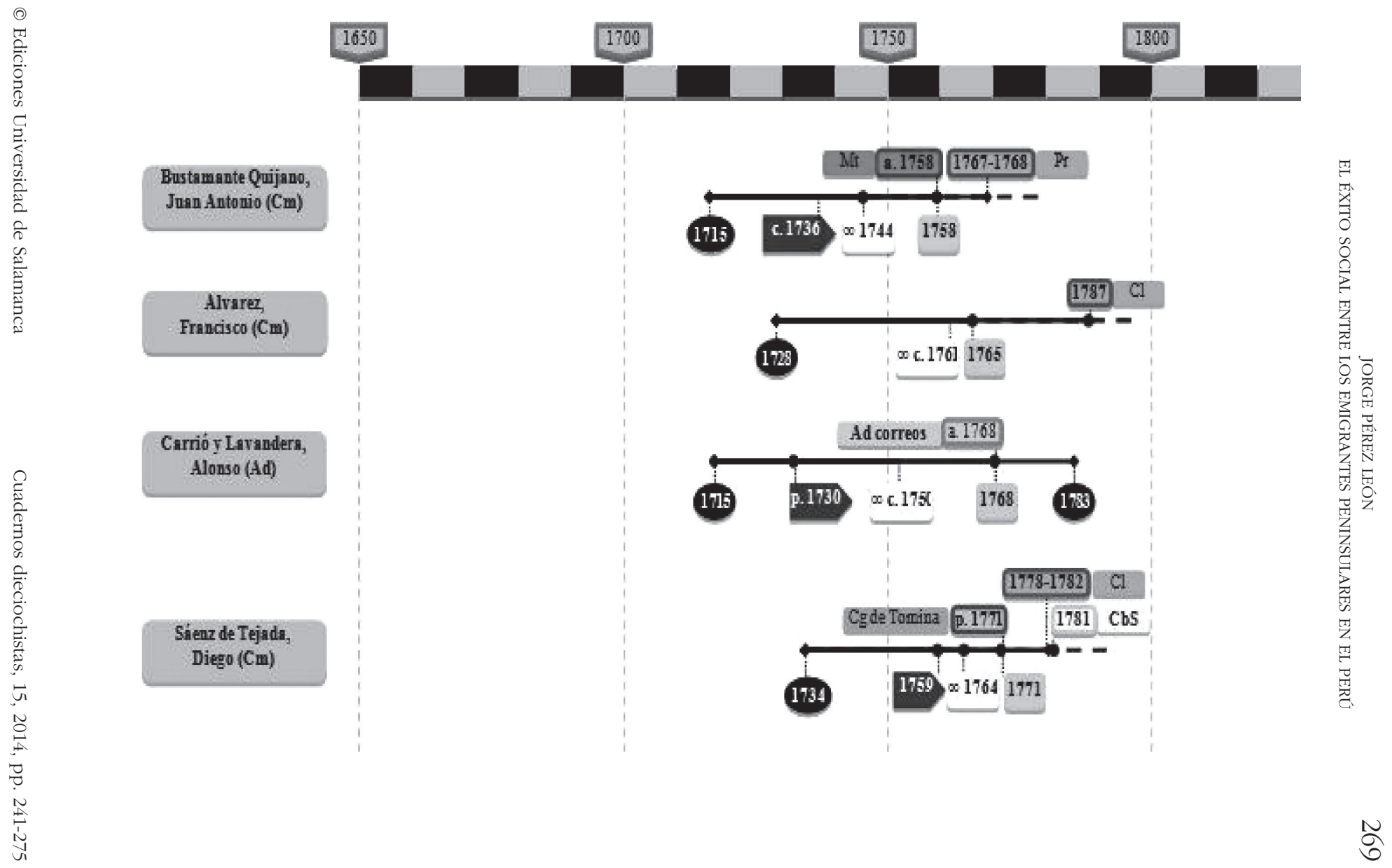




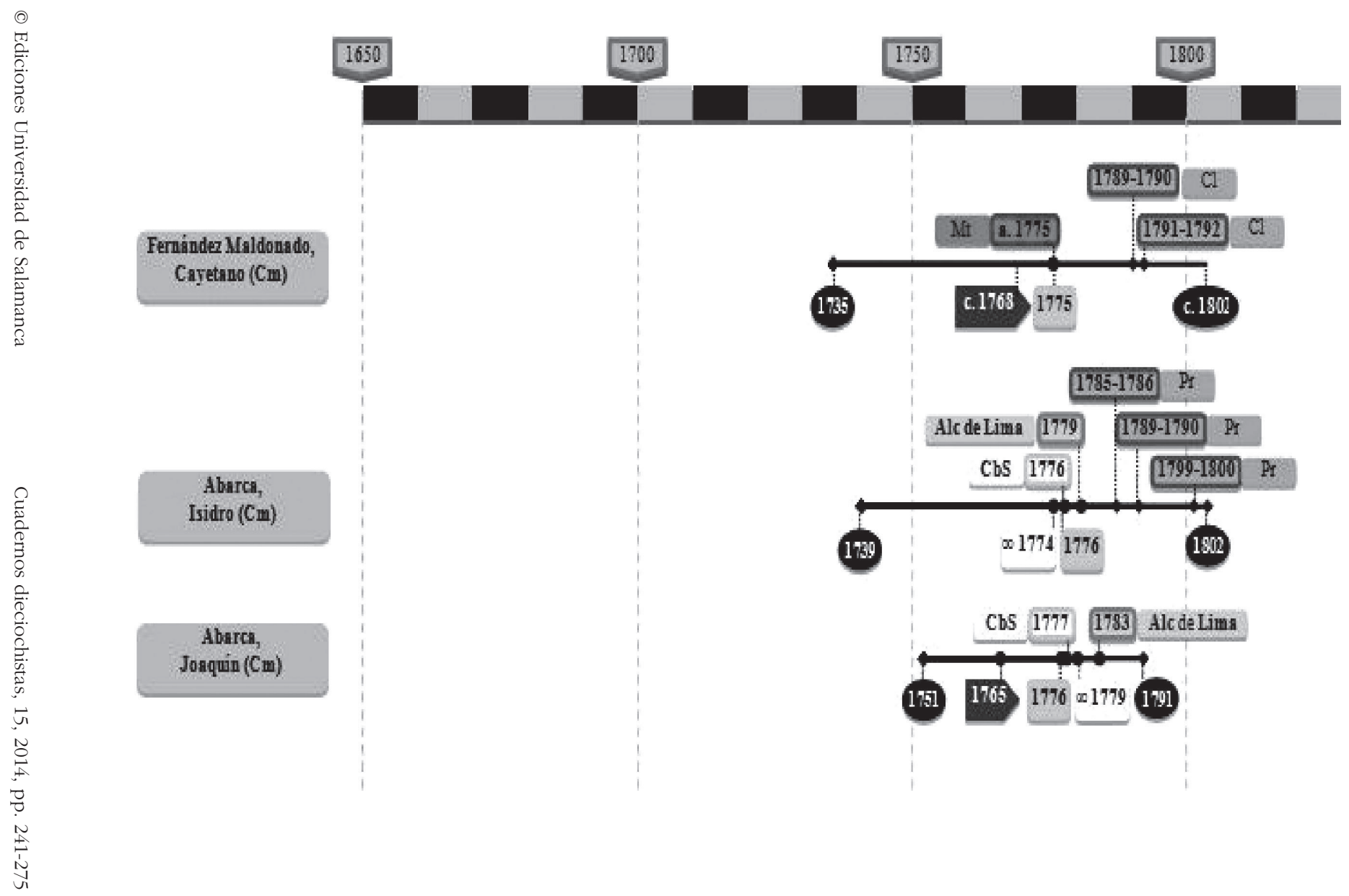

핑

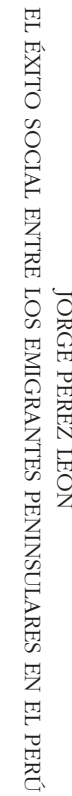




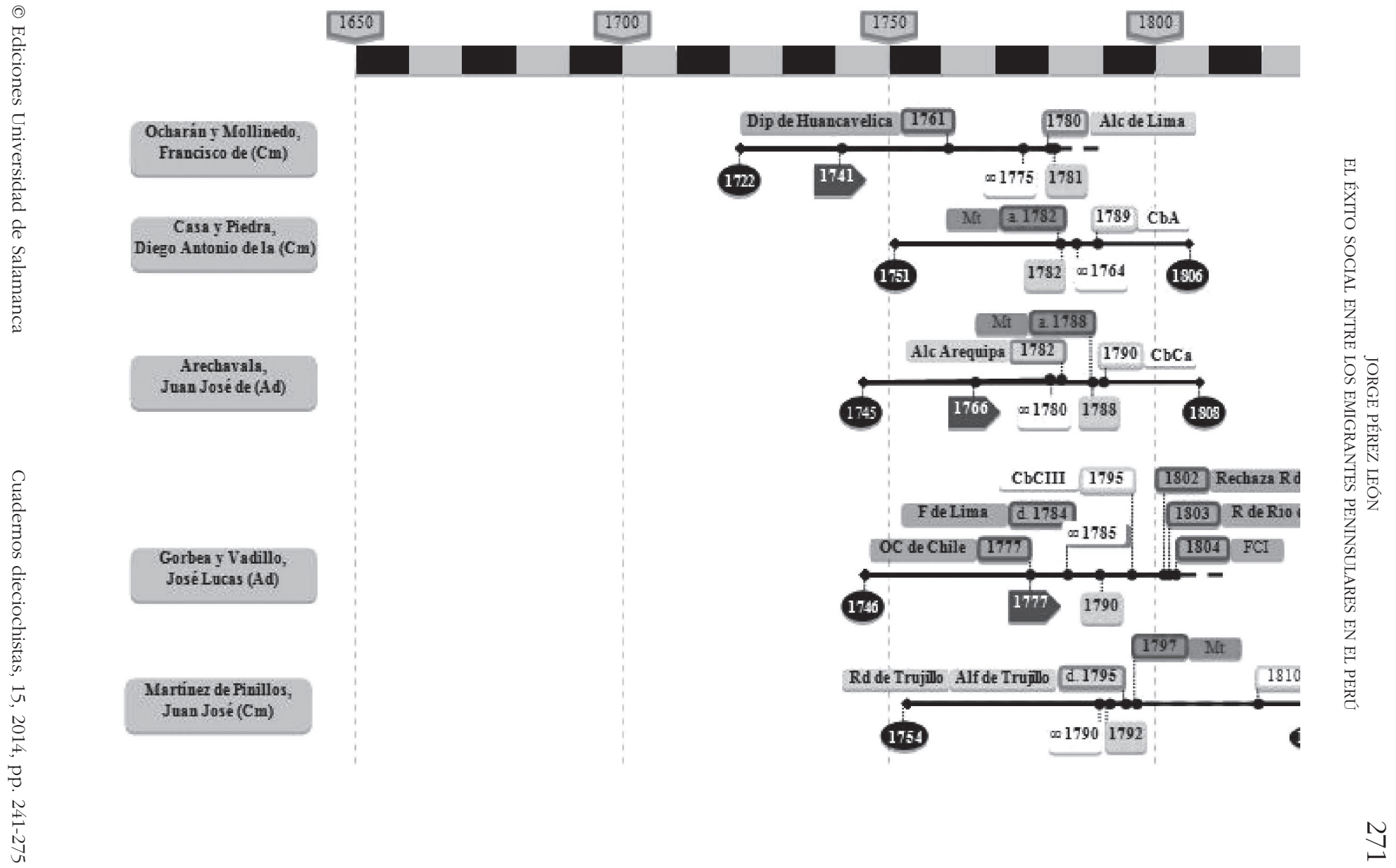




\section{LEYENDA}

Cargos en la Administración real

Cg Corregidor

F Fiscal de Audiencia

FCI Fiscal del Consejo de Indias

OC Oidor de lo civil

R Regente de Audiencia

-------Ramo de Hacienda

Ad Administrador de Rentas Reales

CR Oficial de Caja Real

Cargos municipales
Alf Alférez Real
Alc Alcalde ordinario
Rd Regidor

Cargos vinculados al Consulado de comercio

Cl Cónsul del Consulado

Dip Diputado del Consulado

Pr Prior del Consulado

Militares y milicianos

Mt Grado de oficial en milicias

Órdenes militares

CbA Caballero de la Orden de Alcántara

CbCa Caballero de la Orden de Calatrava

CbCIII Caballero de la Orden de Carlos III

Cbs Caballero de la Orden de Santiago

Otros

a. antes de la fecha

d. después de la fecha

$\infty$ Matrimonio

Fecha de inicio de proceso de hidalguía

1760. Fecha de paso a América

1800 Fecha de bautismo/muerte 


\section{BiBLIOGRAFÍA}

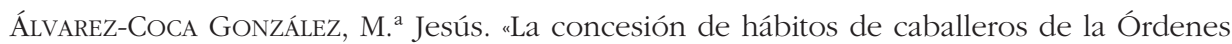
Militares: procedimiento y reflejo documental (s. XVI-XIX)". Cuadernos de Historia Moderna, 1993, 14, pp. 277-297.

ANES FERnÁNDEZ, Lidia. "Comercio con América y títulos de nobleza: Cádiz en el siglo XVIII". Cuadernos Dieciochistas, 2001, 2, pp. 109-149.

ANeS FERnÁndeZ, Lidia. "Nobleza asturiana en el siglo XVIII”. En FAyA DíAZ, M. å Ángeles (coord.). La nobleza en Asturias del Antiguo Régimen. Oviedo: KRK, 2004.

Bromley, Juan. "Hermanos 24 de la Archicofradía de la Santísima Veracruz de Lima entre los años 1775 y 1787". Revista del Instituto de Investigaciones Genealógicas, 1963, 13, pp. 137-154.

Cerrillo Cruz, Gonzalo. Los familiares de la Inquisición española. Valladolid: Junta de Castilla y León, 2000.

Felices DE LA Fuente, M. ${ }^{a}$ del Mar. La nueva nobleza titulada de España y América en el siglo XVIII (1701-1746). Entre el mérito y la venalidad. Almería: Universidad de Almería, 2012.

GUARDA GEYWITZ, Gabriel. La sociedad en Chile austral antes de la colonización alemana, 1645-1845. Santiago: Universidad Católica de Chile, 1979.

Hampe MarTínez, Teodoro. "Las Tradiciones Peruanas y el imaginario de la nobleza titulada del virreinato". Revista de Indias, 2001, LXI, 222, pp. 331-344.

Humboldt, Alejandro de. Ensayo político sobre el reino de la Nueva España (estudio preliminar, revisión de texto, cotejos, notas y anexos de Juan Antonio Ortega y Medina). México: Porrúa, $1973^{2}$.

Imízcoz BeunZA, José M. ${ }^{a}$ "El patrocinio familiar. Parentela, educación y promoción de las élites vasco-navarras en la monarquía borbónica”. En CHACón Jiménez, Francisco y Hernández Franco, Juan (eds.). Familia, poderosos y oligarquías. Murcia: Universidad de Murcia, 2001, pp. 93-130.

KONETZKe, Richard. Colección de documentos para la historia de la formación social de Hispanoamérica, 1493-1810. Madrid: CSIC, 1962.

LADD, Doris M. La nobleza mexicana en época de la Independencia, 1780-1826. 1. ${ }^{\mathrm{a}} \mathrm{ed}$. México: Fondo de Cultura Económica, 1984.

Langue, Frédérique, "Las élites en América española, actitudes y mentalidades". Boletín Americanista, 1992-1993, pp. 42-43.

Lira MonTt, Luis. "La prueba de hidalguía en el derecho indiano". Hidalguía, 1977, 140, pp. 77-83.

Lira MONTT, Luis. "Reflexiones en torno del llamado "matriarcado" colonial hispanoamericano". Hidalguía, 1988, 206, pp. 15-28.

Lohmann Villena, Guillermo. Los ministros de la Audiencia de Lima en el reinado de los Borbones: 1700-1821. Sevilla: Escuela de Estudios Hispano-Americanos, 1974.

Lohmann Villena, Guillermo. Los regidores perpetuos del cabildo de Lima (1535-1821). Sevilla: Diputación Provincial de Sevilla, 1983.

Lohmann Villena, Guillermo. "La Ilustre Hermandad de Nuestra Señora de Aránzazu de Lima". En Arana Pérez, Ignacio (coord.). Los vascos y América. Ideas, hechos, hombres. Madrid: Espasa-Calpe, 1990, pp. 203-213.

LOHMANN VILLENA, Guillermo. "Los comerciantes vascos en el virreinato peruano". En Escobedo Mansilla, Ronald [et al.]. Los vascos y América, Actas de las Jornadas sobre 
el comercio vasco con América en el siglo XVIII y la Real Compañia Guipuzcoana de Caracas en el II Centenario de Carlos III. Bilbao: Laida, 1989, pp. 53-106.

LuQue AlCalde, Elisa. La cofradia de Aránzazu de México (1691-1799). Pamplona: Eunate, 1995.

MARCHENA FERNÁNDEZ, Juan. Ejército y milicias en el mundo colonial americano. Madrid: MAPFRE, 1992

MARChENA FERnÁNDEZ, Juan. "Ejército y cambio social en la América de fines del XVIII". En VV. AA. La América española en la Época de las Luces: tradición-innovación-representaciones: (Coloquio franco-español, Maison des Pays Ibériques, Burdeos, 18-20 septiembre 1986). Madrid: Ediciones de Cultura Hispánica, 1988, pp. 59-97.

Martínez Martín, Carmen. "Linaje y nobleza del virrey don José Manso de Velasco, conde de Superunda". Revista Complutense de Historia de América, 2006, 32, pp. 269-280.

Maruri Villanueva, Ramón. "De la vieja Montaña a la Nueva España: los caminos hacia la nobleza titulada (siglo XVIII)». En ARANDA Pérez, Francisco José (coord.). Burgueses o ciudadanos en la España moderna. Cuenca: Universidad de Castilla-La Mancha, 2003, pp. 257-302.

MARURI VILlanueva, Ramón. "Poder con poder se paga: títulos nobiliarios beneficiados en Indias (1681-1821)". Revista de Indias, 2009, vol. LXIX, 246, pp. 207-240.

Mateo Pérez, Armando. "La "fundación de patronatos": fuente para el estudio de una realidad espiritual, social y artística". En Porres, Rosa (dir.). Aproximación metodológica a los protocolos notariales de Álava (Edad Moderna). Bilbao: Universidad del País Vasco, 1996, pp. 357-378.

MAZzeo DE VIVÓ, Cristina. "Mecanismos de supervivencia en la élite mercantil limeña a fines del siglo xviii y principios del XIX". En SCHRÖTER, Bernd y BüsCHGES, Christian (eds.). Beneméritos, aristócratas y empresarios. Identidades y estructuras sociales de las capas altas urbanas en la América hispánica. Madrid: 1999, pp. 67-82.

MAZZEO DE VIVÓ, Cristina. "Estrategias de control social y económico en la élite mercantil de Lima en su tránsito de la colonia a la repúblican. En Guerra, Margarita y Rouluión, Denisse (eds.). Historias paralelas. Actas del Primer Congreso de Historia Perú-México. Lima: Colegio de Michoacán-Pontificia Universidad Católica del Perú, 2005, pp. 281310.

Mendiburu, Manuel de. Diccionario histórico-biográfico del Perú, 2. ${ }^{a}$ ed. Lima: Imprenta de J. Francisco Solís, 1931.

NAVARro García, Luis. "Nobleza criolla y milicia en México, 1766". Temas Americanistas, 2002, 15, pp. 64-72.

PARRÓN SALAS, Carmen. "Religiosidad y finanzas en el consulado de Lima, 1778-1821". Hispania Sacra, 1992, 44, pp. 590-597.

PARRÓN SALAS, Carmen. "Burguesía mercantil y estado colonial. Los comerciantes de Lima (1778-1821)". En ENCISO ReCIO, Luis Miguel (coord.). La burguesía española en la Edad Moderna: Actas del Congreso Internacional celebrado en Madrid y Soria los dias 16 a 18 de 1991. Valladolid: Universidad de Valladolid, 1996, II, pp. 711-724.

PARRÓn SALAS, Carmen. "Nuevas perspectivas del Perú colonial y su transición al mundo contemporáneo". En Vila VILAR, Enriqueta y Kuethe, Allan J. (eds.). Relaciones de poder y comercio colonial. Sevilla: Escuela de Estudios Hispano-Americanos, 1999, pp. 206-208.

PÉREZ LeÓn, Jorge. "Emigración al Nuevo Mundo y la "fuerza del origen": su huella en los procesos de hidalguía”. Naveg@mérica. Revista electrónica de la Asociación Española 
de Americanistas [en línea]. 2013, n. ${ }^{\circ}$ 10. Disponible en http://revistas.um.es/navegamerica [Consulta: 1-04-2013].

QuinTERO, Inés. "Los nobles de Caracas y la Independencia de Venezuela". Anuario de Estudios Americanos, julio-diciembre 2007, 64-2, pp.

RiZo PATRÓn, Paul. "Vinculación parental y social de los comerciantes de Lima a fines del periodo colonial”. En MAZzEO, Cristina Ana. Los comerciantes limeños a fines del siglo XVIII. Capacidad y cohesión de una élite, 1750-1825. Lima: Pontificia Universidad Católica del Perú, 1999, pp. 17-27.

Rizo-Patrón Boylan, Paul. Linaje, dote y poder: la nobleza de Lima de 1700 a 1850. Lima: Pontificia Universidad Católica del Perú, 2001.

SÁncheZ-Concha BARRIOS, Rafael. "La devoción a la Cruz en el Perú y la Archicofradía de la Vera Cruz de Lima (siglos XVI-XVIII)". En IV Congreso Internacional de Hermandades y Cofradias de la Santa Veracruz celebrado en Zamora los dias 25, 26 y 27 de septiembre de 2008. Zamora: 2008.

Socolow, Susan. Los mercaderes del Buenos Aires virreinal: familia y comercio. Buenos Aires: Ediciones La Flor, 1991.

STABili, M. ${ }^{a}$ Rosaria. "Hidalgos americanos. La formación de la élite vasco-castellana de Santiago de Chile en el siglo XVIII. En SCHrÖTER, Bernd y BüsChges, Christian (eds.). Beneméritos, aristócratas y empresarios. Identidades y estructuras sociales de las capas altas urbanas en la América hispánica. Madrid: Vervuert, 1999, pp. 133-155.

TuRISO SEBASTIÁn, Jesús. Comerciantes españoles en la Lima borbónica: anatomía de una élite de poder. Valladolid: Universidad de Valladolid, 2002.

Unamuno, Miguel de. Obras completas. Madrid: Fundación José Antonio de Castro, 2007.

Unzueta ECHEVARRía, Antonio. "Los vascos de Arequipa y la cofradía y capilla de Nuestra Señora de Aránzazun. En Álvarez Gila, Óscar y ARrieta Elizalde, Elisa (eds.). Las huellas de Aránzazu en América. I Congreso Internacional "Aránzazu y los franciscanos vascos en América", celebrado del 11 al 15 de diciembre de 2001. Donostia: Eusko Ikaskuntza, 2001, pp. 115-137.

Villalba Pérez, Enrique. «La Orden de Carlos III: ¿Nobleza reformada?». En Coloquio internacional Carlos III y su siglo: actas. Madrid: Universidad Complutense de Madrid, 1990, II, 671-682. 